\title{
WestVirginiaUniversity
}

THE RESEARCH REPOSITORY @ WVU

Graduate Theses, Dissertations, and Problem Reports

2013

\section{White Collar Crime and Morality: How Occupation Shapes Perception}

Marshall Schmidt

West Virginia University

Follow this and additional works at: https://researchrepository.wvu.edu/etd

\section{Recommended Citation}

Schmidt, Marshall, "White Collar Crime and Morality: How Occupation Shapes Perception" (2013).

Graduate Theses, Dissertations, and Problem Reports. 422.

https://researchrepository.wvu.edu/etd/422

This Thesis is protected by copyright and/or related rights. It has been brought to you by the The Research Repository @ WVU with permission from the rights-holder(s). You are free to use this Thesis in any way that is permitted by the copyright and related rights legislation that applies to your use. For other uses you must obtain permission from the rights-holder(s) directly, unless additional rights are indicated by a Creative Commons license in the record and/ or on the work itself. This Thesis has been accepted for inclusion in WVU Graduate Theses, Dissertations, and Problem Reports collection by an authorized administrator of The Research Repository @ WVU. For more information, please contact researchrepository@mail.wvu.edu. 
White Collar Crime and Morality: How Occupation Shapes Perception Marshall Schmidt

Thesis submitted to the

Eberly College of Arts and Sciences

at West Virginia University

in partial fulfillment of the requirements for the degree of

Master of Arts

in

Sociology

Lisa Dilks, Ph.D., Chair

James Nolan, Ph.D.

Joshua Woods, Ph.D.

Department of Sociology and Anthropology

Morgantown, West Virginia

2013

Keywords: White-collar Crime, Perceptions, Status Characteristics Theory

Copyright 2013 Marshall Schmidt 


\section{ABSTRACT \\ White Collar Crime and Morality: How Occupation Shapes Perception}

\section{Marshall Schmidt}

White-collar crime is on the rise in the United States and globally. The general public has historically been seen as apathetic to white-collar criminals and their crimes; however more recent studies have shown that prior conclusions on perceptions of white-collar criminals may have been inaccurate. In this paper, I examine the role that occupation has in forming perceptions of white-collar criminals. Using Status Characteristics Theory, a structural social psychological theory that links an individual's status characteristics to evaluations of their morality, trustworthiness and competency, vignette experiments are constructed that allow for offender status and offense seriousness in various white collar crime scenarios to be studied. The research finds that occupation as a status characteristic does exist and has an impact on criminal perceptions, but its effect is diminished when offense seriousness is also taken into consideration. 
Table of Contents

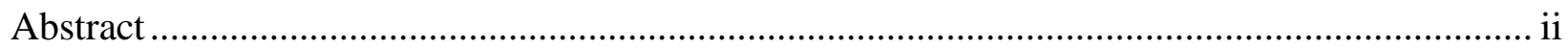

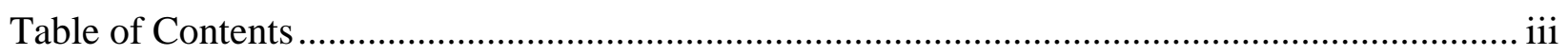

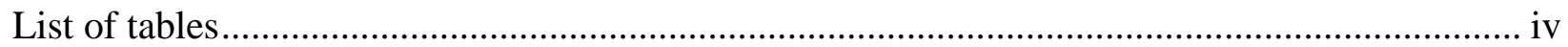

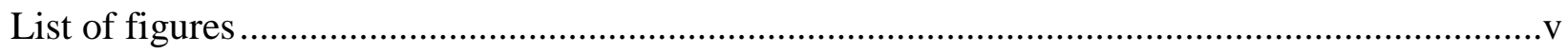

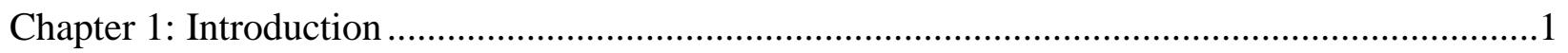

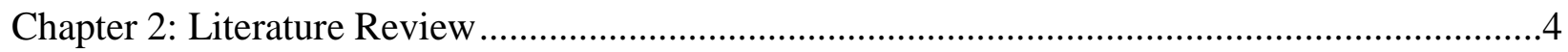

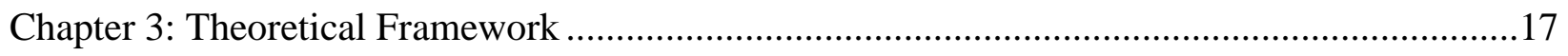

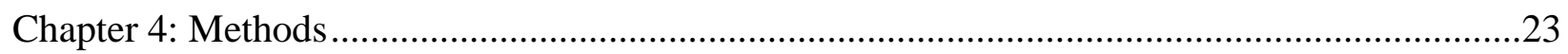

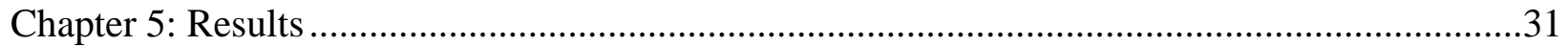

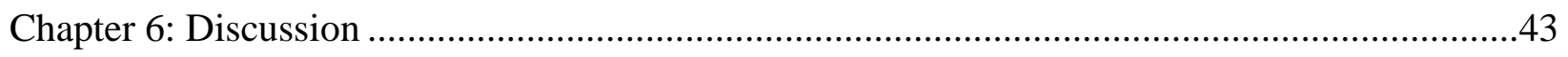

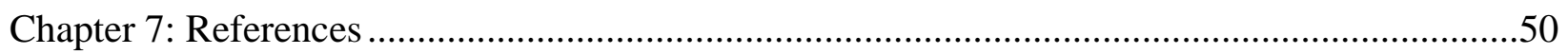

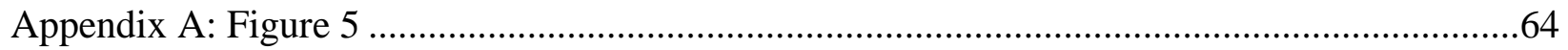

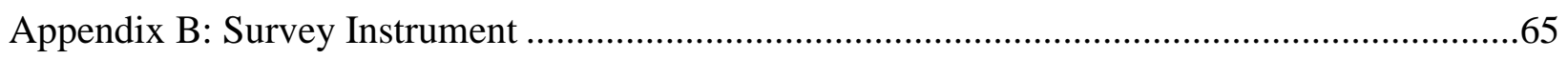

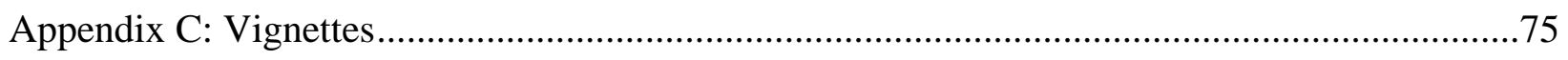




\section{List of Tables}

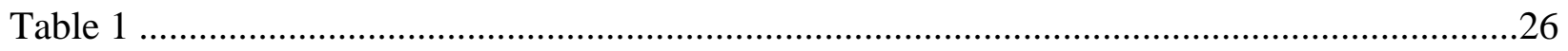

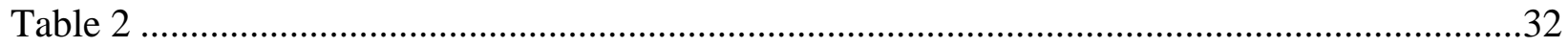

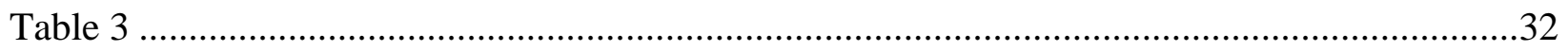

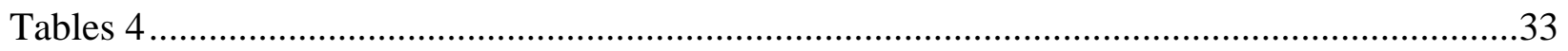

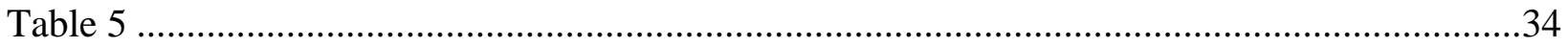

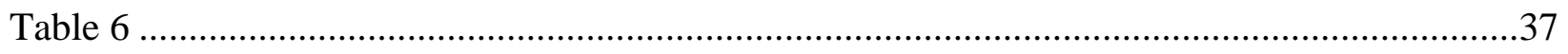

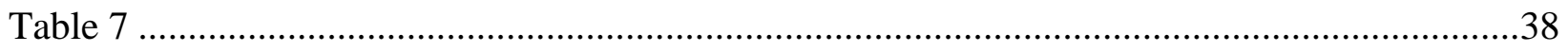

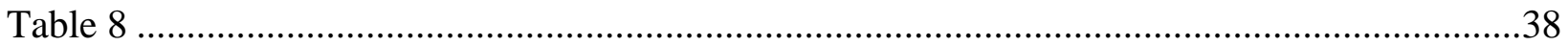

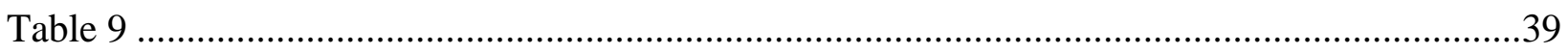

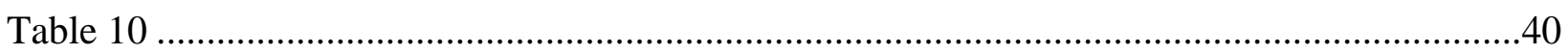

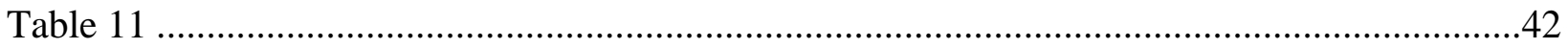




\section{List of Figures}

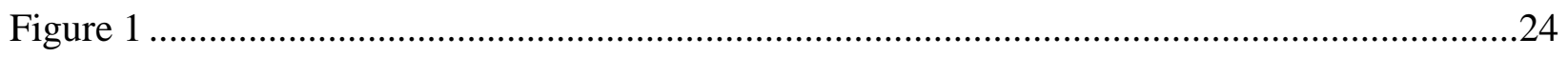

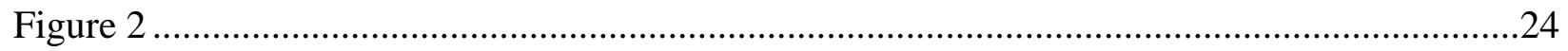

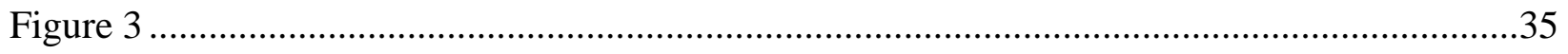

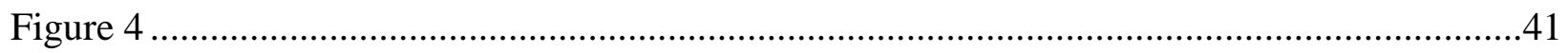

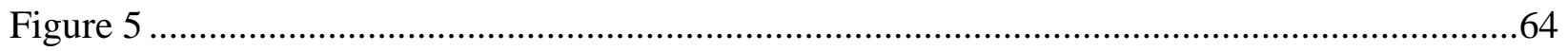


Arm your car, lock your doors, do not talk to strangers, and mace or pepper spray anyone who comes near. Americans are vigilant about crime, and they are tough on crime. We put up cameras, start neighborhood watch programs, arm ourselves, and put bad guys in prison. We are conditioned and cautioned to be fearful at all times about the ever lurking criminal threat that hangs in the shadows waiting to pounce. What about the criminal lurking in plain sight?

White-collar crime is a growing problem in the United States and globally, but it seems that street crime and property crime always dominate the public's sphere of concern (Holtfreter et al. 2008). The prevalence of street crime and property crime resonates most with the general public, even though they may have never ultimately been affected by them. As such, public attention concerning crime is largely aimed at eliminating easily observable and traditional crimes like street crime and property crime that do comparatively less damage than white-collar criminal offenses (Holtfreter et al. 2008; Hamilton, Lee, and Sanders 1996; Roberts 1992).

Estimates from the FBI as well as the Association of Certified Fraud Examiners determine the annual cost of white-collar crimes to be between $\$ 300$ to $\$ 660$ billion (Association of Certified Fraud Examiners 2005; Holtfreter et al. 2008) compared to $\$ 17.6$ billion for personal and household crimes (Holtfreter et al. 2008). White-collar crime in fact does significantly affect the everyday U.S. citizen (National White Collar Crime Center 2010). The Bureau of Justice Statistics 2008 Criminal Victimization Survey found that about $13.5 \%$ of households surveyed were victimized by property crime, $1.93 \%$ of households were victims of violent crime, and $24.2 \%$ of households reported being victims of white-collar crime (The Bureau of Justice Statistics 2008). The Bureau of Justice Statistics Victimization studies also show a decrease in violent crime victimization of $41.2 \%$, as well as a $32 \%$ decrease in property crime victimization since 1999 (The Bureau of Justice Statistics 2008). The FBI's Uniform Crime Reports since 
2000 also show a $15.2 \%$ decrease in violent crime reports, and a $16.1 \%$ decrease in property crime reports (FBI 2007). While white-collar criminals and their actions are garnering more attention, their crimes are still perceived of differently than other types of crime (Holtfreter et al. 2008; Schoepfer, Carmichael, and Piquero 2007).

Different perceptions of the morality of street offenders is pervasive within the criminology literature, and is reflected by differential sentencing of offenders and levels of moral outrage expressed by the public and portrayed in the media (Hans and Erman 1989; Gordon et al 2001; Schoepfer et al. 2007). Street criminals are treated and perceived of differently based on certain attributes like race, gender, age, etc. (Blumstein et al 1983; Spohn 2009; Spohn and Holleran 2000; Steffensmeier, Ulmer, and Kramer 1998). While it has been established that there is a difference in the perceptions of morality and crime severity among offenders of various sociodemographic groups in street and property crime, little has been done in this area concerning such perceptions of various white-collar offenders. A recent survey found that crimes committed by high-status offenders were perceived of as slightly more troubling than those committed by low-status persons (National White Collar Crime Center 2010). However the findings of the National Public Survey on White Collar Crime relative to perceptions of offender status were minimal with a very small difference in effect, and need further probing and retesting before definitive conclusions can be drawn. A comprehensive review of the literature on perceptions of white-collar crime shows that little other research has been done principally investigating differences in perceptions of morality among white-collar offenders and presents a significant void in the literature on white-collar crimes.

White-collar criminals and their crimes might be attracting more attention than in the past, but essentially an enterprise that costs billions of dollars a year is not thought of as an imminent 
social threat. In this research, I argue that the perceptions of white-collar criminals mitigate the severity of their crimes. Furthermore, essential to such perceptions is the white-collar criminal's occupation. There is a hierarchical ranking in society that has been reaffirmed through both longitudinal and cross-cultural studies that provide empirical evidence that occupations are ranked (Glenn 1975; Hodge and Rossi 1978; Marsh 1971; Nakao and Treas 1994). Specifically, we judge one occupation as more worthy than another occupation, resulting in a higher amount of prestige accorded to those occupations we deem as more worthy in comparison to others (Treiman 1977). We trust those in higher occupational prestige positions to perform relevant occupational tasks competently and morally because of the occupation that they hold and the prestige associated with it. Therefore, a person's occupation can have real implications for how they are perceived. Following from previous research (LaFrentz and Spohn 2006), occupation can assuage perceptions of crime severity and offender dangerousness, such that because of a person's occupation there is either a greater or lesser perceived amount of dangerousness of them committing a crime as well as a greater or lesser perceived amount of severity associated with the particular crime in relation to the criminal's occupation. More occupational prestige can result in lowered perceptions of dangerousness and severity, possibly explaining why whitecollar criminals are not perceived as an imminent social threat.

In order to empirically assess the link between occupational prestige and perceptions of culpability and severity of white-collar crime and criminal offenders, I propose a vignette experiment that manipulates offender status and crime severity in various white-collar crime scenarios. The vignettes are theoretically driven by Status Characteristics Theory, a structural social psychological theory that links an individual's status characteristics - race, gender, age, education, and occupation - to evaluations of their morality, trustworthiness and competency 
(Berger et al. 1977). Under this theoretical framework, I assess the perceptions of white-collar crime in relation to the crime itself and the morality and occupational prestige associated with particular occupations.

This research contributes to our empirical and theoretical understanding of white-collar crime in numerous ways. First, this project will provide a more comprehensive evaluation of the degree to which a person's occupational status matters in forming perceptions of white-collar criminals. The research will present a new way to extend upon Status Characteristics Theory further evaluating and refining the diffuse status characteristic of occupational prestige. Finally, the research will gauge public opinion and fill a gap in the sociological literature on perceptions of white-collar crime and criminals.

\section{LITERATURE REVIEW}

\section{Defining White-Collar Crime}

Edward Ross developed the idea of “The Criminaloid” in the early 1900's. Ross (1907:45) warned that these individuals were powerful people, whose "actions are harmful but lack that 'brimstone smell' of commonly recognized harms associated with conventional crimes." These criminaloids, or quasicriminals, particularly worried Ross because he believed that unlike common criminals, public opinion at the time had not yet turned on the criminaloid (Ross 1907). Ross was convinced that America needed to shift its attention from the plain criminal to the criminaloid because they were people who were committing heinous practices, but escaped the criticisms of public opinion. The Criminaloid comes off well because his "spiritual attitude" is not truly that of a criminal (Ross 1907). The law may be able to find the Criminaloid guilty, but Ross did not believe the Criminaloid was being exposed for what they truly were. Therefore not only were Criminaloids not culpable in their own eyes, but in the eyes of the public as well. 
Morality was at the essence of Ross's idea of the Criminaloid, and he believed that the Criminaloid would only be stopped when "the growth of morality overtakes the growth of opportunity to prey" (Ross 1907:44-45).

Edwin Sutherland was also concerned with this idea of a criminal appearing not to be what it truly was. Sutherland's concept grew out of Ross's idea of the Criminaloid, and he coined the term white-collar crime (Ermann and Lundman 2002). "White collar crime may be defined approximately as a crime committed by a person of respectability and high social status in the course of his occupation" (Sutherland 1983:2). Sutherland was so convinced that the crimes of the business class and those being done in the "suites" by powerful people were more important than the crimes of those in the streets that he made it the subject for his 1939 American Sociological Association President's Address (Ermann and Ludman 2002; Sutherland 1983).

The definition of white-collar crime continues to be a highly debated topic. Wheeler et al. (1988:332) said "the evolution of white collar crime has been marked by changes in meaning that often preserve rather than reduce fundamental ambiguities." For the multitude of definitions that exist, one claiming its superiority over another, they all are, arguably, based in Sutherland's definition of white-collar crime, and they all emphasize a few common components. Specifically, status, occupation, and violation of trust are all crucial elements of any definition of white-collar crime and they highlight what separates white-collar crime from other types of crime.

Though violation of trust is not explicitly stated within Sutherland's definition, it is implicit in the commission of crime through an occupation. All crimes can be argued to be violations of trust, but this idea is particularly salient and important to consider because of how trust associated with certain occupations is violated in the commission of a white-collar offense. 
Sutherland's definition of white-collar crime also includes a component of respectability and high social status. White-collar offenses have evolved since Sutherland coined the term and we now know that anyone can commit white-collar crime. Respectability and high social status then do not necessarily have to be conceived of in a connotative sense. Rather respectability and high social status are relative to the occupational position of an offender and can be thought of in a comparative sense to other occupations. A recent study by Van Slyke (2009) has acknowledged the fact that white-collar crimes' broadened definitions have actually "perpetuated status-based disparities the very concept was designed to bring to light" (Van Slyke 2009:ix). While some may argue that the idea of high respectability or status must be divorced from the idea of whitecollar crime, and that we must consider only the offense while ignoring the offender, it can also be argued that the offender in white-collar crime is inescapably and intrinsically linked to the crime itself (Piquero and Schoepfer 2010; Schoepfer and Piquero 2006). For example, recent studies by the National White Collar Crime Center which conducts the National Public Survey on White Collar Crime define white-collar crimes as "illegal or unethical acts that violate fiduciary responsibility or public trust for personal or organizational gain" (National White Collar Crime Center 2010).

\section{Perceptions of White-Collar Crime}

Studies of white-collar crime and criminals although increasing, fall short of the plethora of research that has been done on violent and property crimes (National White Collar Crime Center 2005). While there have been a few studies that look at public opinions and interest of whitecollar crime, many of them focus on victimization of the offenses and seriousness, or they compare white-collar crimes to other general crimes (National White Collar Crime Center 2005). Even the Uniform Crime Report which is supposed to collect information on crime, including 
white-collar crimes, only collects information on a very small number of white-collar crimes (National White Collar Crime Center 2010). Simpson and Weisburd (2009) find that there are too few data sets that exist on white-collar crime that could be used for primary and secondary analysis, and that of the research that does exist on white-collar crime very little of it is of high quality or important. Van Slyke (2009) finds that most of the current research done on whitecollar crime is of a descriptive nature rather than explanatory, and that the public opinion research we have largely ignores white-collar crime. Piquero and Schoepfer (2010) assert the same position that white-collar crime has not been paid the research attention that it deserves, and point out the fact that a lot of our understanding of white-collar crime comes as a result of applying theories of street crime to white-collar crime, which we know to be substantially and substantively different (Benson and Kerley 2001; Benson and Moore 1992; Schoepfer and Piquero 2006; Weisburd, Wheeler et al. 1991). This is not to necessarily say that the research done needs to be discounted or that we cannot apply and use theories based on other types of criminality to study white-collar crime. Rather it is important that overall more studies are done, and that many theories are tested in order to more fully study white-collar crime and criminality in general.

Studying perceptions is a very important part of studying social life, and the way that people perceive of crime is "a central aspect of normative culture in general and formal social control in particular" (Stylianou 2003:37). Perceptions of white-collar criminals are historically mixed, constantly shifting, lagging in a sense, and not necessarily in line with reality. Early research showed that white-collar crime was not viewed as a serious crime, especially when compared to crimes either committed against a person or the public (Geis 1973; Sutherland 1949; Wheeler, Mann, and Sarat 1985). 
Cullen, Hartman, and Jonson (2009) examined the evolution of public thought and opinion concerning white-collar crime and find three periods of American history that mark changes in public perceptions of white-collar crime. In the first period, prior to 1970, white-collar crime was thought of as being on the periphery of American criminology and little scholarly and legal attention was paid to it (Cullen et al. 2009). During this time the President's Commission on Law Enforcement and Administration of Justice (1968) found that the public tended to be indifferent to business crimes and to even sympathize with white-collar criminals who had been caught (Cullen et al. 2009; President's Commission 1968). For example, a survey of college students by Reed and Reed (1975) found that only $42 \%$ had heard of white-collar crime, while just $32 \%$ gave a satisfactory definition of it, leading them to the conclusion that knowledge of white-collar crime was not very diffuse and that most people were ignorant of it (Cullen et al. 2009; Reed and Reed 1975). However, the public was not completely indifferent to the offenses of white-collar criminals. A 1969 national poll found that the public viewed a manufacturer of unsafe automobiles as worse than a mugger and a businessman engaged in price-fixing as worse than a burglar (Time 1969).

Many scholars cite a change in thoughts on white-collar crime after the 1970's as a result of the civil rights movement of the 1960's, and Watergate (Cullen et al. 2009; Cullen, Link, and Polanzi 1982; Sutherland 1983). Cullen et al. (2009) also recognize a change in thought staring in the 1970's and continuing into 2000, during which period they argue that there was an increased amount of general knowledge of white-collar crime and a shift to thinking that whitecollar crime was in fact serious. Knowledge of white-collar crime was increasing so much during this period of time that polls show that by the 1980's there was a pervasive belief that business people in their occupation will only act socially responsible when the public interests actually 
coincide with their own self-interests (Cullen et al. 2009). The public now believed white-collar crimes were occurring often and that corporate executives were dishonest, with one poll finding that only $16 \%$ of respondents rated executives' honesty and ethics as 'high' or 'very high' (Cullen et al. 2009; Gallup Poll 1988).

This theme continued into the twenty-second century, with 2000 to the present deemed by Cullen et al. (2009) as the period of transformed attention. General knowledge of white-collar crime grew from the 1970 's to 2000 , but the period after 2000 is seen as the point when public opinion came to actually abhor white-collar crime and openly and definitively damn offenders (Cullen et al. 2009). A number of recent studies show that the public has little tolerance for white-collar crime, that there is a change in the importance and seriousness of white-collar crime relative to street crime, and that people are in favor of harsher punishment for white-collar criminals (Cullen et al. 2009; Holtfreter et al. 2008; National White Collar Crime Center 2000, 2005; Piquero, Carmichael, and Piquero 2008; Schoepfer, Carmichael, and Piquero 2007; Unnever, Benson, and Cullen 2008). Though studies show the historical progression and change in thought on white-collar crime, the fact that it occurs at such a high rate, coupled with increased public awareness and condemnation, means that understanding perceptions of it are even more important.

While early research pointed to the fact that white-collar crime was not considered a serious or troublesome crime necessary of attention in the eyes of the public, later research suggests that prior conclusions may have been premature. For example, early research on crime seriousness consensus shows that norms for crimes were fairly constant across all subgroups tested, and white-collar crime was viewed as a non-serious crime on par with other victimless crimes (Rossi et al. 1974). However, Schrager and Short (1980) introduced controls for the type of white-collar 
crime factoring in the seriousness of the offense and found that the seriousness rankings of white-collar crime were much higher than what had previously been found. Unlike earlier research that found all white-collar crimes to be considered not serious, Schrager and Short (1980) also found that organizational crimes that incurred injuries or death were ranked as very serious and even on the same level as other, more conventional crimes.

Further research in the 1980's continued to show the evolution of perceptions of white-collar criminals and their crimes. Perceptions of more intangible and less well known white-collar crimes, like price fixing, defrauding customers, and income tax fraud continued to be ranked as less serious than other crimes overall (Cullen 1982; Cullen et al. 1983). However the overall perceptions of white-collar crime seriousness increased and were found in some instances to be ranked as more serious than certain types of homicide (Cullen 1982; Cullen et al. 1983). The white-collar crimes of manufacturing unsafe products and selling of contaminated food were perceived of as worse than armed robbery and arson, and people were found to be more in favor of imprisonment for embezzlers and antitrust violators rather than burglars and prostitutes (Cullen et al. 1985).

The public has for a time realized that white-collar crime is a problem and that it deserves punishment (Clinard and Yeager 1980; Cullen et al. 1983; Grabosky, Braithwaite, and Wilson 1987; Hans and Erman 1989; Schrager and Short 1978). Early research showed the general public to be indifferent to crimes of the elite; however more recent research has shown that the public thinks certain types of white-collar crimes are in fact serious (Piquero, Carmicheal, and Piquero 2008). Perceptions have changed over time especially with the publicity of recent large scale white-collar crimes, like those of Enron, Worldcom, Martha Stewart, Bernie Madeoff, etc (Burton, Karlinsky, and Blanthorne 2005). Podgor $(2007,2011)$ advances that perceptions of 
white-collar crime and criminals have changed to be more serious and are evidenced by more severe sentencing.

Rosenmerkel (2001), through a sampling of Midwestern college students, found that whitecollar crimes were seen as less serious overall than violent crimes, but more serious, wrongful, and harmful than property crimes. Burton et al. (2005) when looking at perceptions of tax evasion found support for prior research that suggests people do not perceive white-collar offenses to be as serious as violent offenses but are seen as more serious than most property offenses. Burton et al. (2005) also found that tax evasion was viewed by test subjects as on par with other violations worthy of a maximum sentence of six months in jail, but most likely would be punished with a small fine. Isenring (2008) found that previous assumptions about the public's indifference to white-collar crime were inaccurate, but that even though white-collar crime was seen as serious, respondents were still more punitive of ordinary crimes. Piquero et al. (2008) when looking at perceptions of seriousness of white-collar and street crimes, found that in four of the six comparisons that white-collar crime was perceived to be more serious than street crime. The 2010 National Public Survey on White Collar Crime found that: 1) respondents viewed white-collar crime as slightly more serious than traditional crime; 2) that organizational offenses were viewed more harshly than individual offenses; and 3) that crimes committed by high status offenders were more troubling than those committed by low status offenders (National White Collar Crime Center 2010).

\section{Perceptions of White-Collar Criminals}

The focus of the research on perceptions of criminality relies on responses related to perceptions from individuals based on comparing different types of white-collar crime to other types of white-collar crime, comparing white-collar crimes to other non white-collar crimes, and 
questioning victimization rates (Cullen et al. 1982,1983; Evan, Cullen, and Dubeck 1993; Geis 1973; Sutherland 1949; Goff and Nason-Clarke 1989; Hoffman and Hardyman 1986; Rossi et al. 1974; Wheeler, Mann, and Sarat 1985). More recent research on white-collar crime and perceptions of criminality has focused on comparing different types of crime, and attempting to ascertain perceptions of comparative seriousness, morality, and perceived chances of being caught in conjunction with sanctioning (Burton, Karlinsky, and Blanthorne 2005; Douhou, Magnus, Van Soest 2011; Gordon et al. 2001; Isenring 2008; Kwan et al. 2002; Levi 2008; McCreath 2001; National White Collar Crime Center 2000, 2005, 2010; Piquero, Carmicheal, and Piquero 2008; Stylianou 2003).The literature on particular perceptions of white-collar criminals is very limited (Cullen et al. 2008), and relies heavily on comparing white-collar criminals to street criminals or property offenders. Gottfredson and Hirschi (1990) proposed a general theory of crime in which they asserted that the difference between street and white-collar crime was more of an offense rather than an offender difference, such that both types of offenders would likely share similar characteristics. However, Wheeler et al. (1988) and Benson and Moore (1992) tested Gottredson and Hirschi's theory on large samples of convicted whitecollar and street criminal offenders and found that as a group white-collar criminals were very clearly different than the common criminal. Specifically, Wheeler et al. (1988) found that 1) white-collar criminals had higher levels of education than common offenders and the general public; 2) they had higher levels of steady employment than common criminals; and 3) that the typical white-collar offender was a white, 40-year-old male while the typical common criminal offender was a 30-year-old, black male (Wheeler et. al 1988). Additionally, Benson and Moore (1992) found that overall white-collar criminals were much less involved in crime than common criminals, concluding that 1) $31 \%$ of white-collar criminals have a prior arrest while $81.1 \%$ of 
common criminals have a prior arrest, and 2) the mean number of arrests for white-collar criminals is much smaller at 1.79 than common criminals at 5.63 (Benson and Moore 1992). Benson and Kerley (2001) when looking at white-collar criminals convicted in federal courts, found that white-collar criminals when compared to street criminals were more likely to be involved in social and community groups as well as church or religious activities.

Perceptions of criminals in general can affect how they are judged and ultimately what sentence they may serve, but they become particularly salient and relevant when looking at white-collar criminals. Van Slyke (2009) illustrates this idea by citing the 1976 Supreme Court decision in Gregg v. Georgia in which the Supreme Court found that "public opinion is a valid justification for state criminal punishment practices" (Van Slyke 2009:1). Recent polls have shown that people do not believe CEO's act morally and that they are losing confidence in business people overall (Cullen et al. 2008). In a recent Bloomberg Poll done by the Los Angeles Times, when asked about the ethics of CEOs no one chose 'always ethical,' one in three selected 'mostly ethical,' while $44 \%$ chose 'not too ethical,' and 12\% chose 'not ethical at all' (Cullen et al. 2008; Los Angeles Times 2007). A 2002 CBS news poll found that two of every three respondents said that most American corporate executives were dishonest (CBS 2002; Cullen et al. 2008). A 2002 Time/CNN poll found that $71 \%$ of those surveyed thought the typical CEO to be less honest and ethical than the average person, with $72 \%$ of respondents also rating the moral and ethical standards of CEOs of major corporations as 'fair 'or 'poor' and $21 \%$ rating them as 'good' or 'excellent' (Cullen et al. 2008; Time/CNN 2002). A 2004 Los Angeles Times poll found that 3 in 4 Americans believed that only 'some of the time' or 'hardly ever' could they trust the executives in charge of major companies in the United States, and that 50\% of the people polled believed cases of wrongdoing among chief executives or corporations was a 
widespread problem in which many business executives were taking advantage of a system that is failing (Cullen et al. 2008; Los Angeles 2004).

Few studies have considered the idea of social status and how it relates to perceptions and punitiveness. Walker (1978) looked at how monetary amount lost in the commission of an offense and offender social status factored into determinations of seriousness. She found that the actual amount of money lost was significant, but that the offender's social status had no impact on seriousness determinations (Walker 1978). O'Connor (1984) compared perceptions of what he termed violent offenders (traditional crime offenders) and swindlers (white-collar criminals). He found that the violent offender was characterized as "single, male, of low social status, in his twenties, had minimal education, and worked in an unskilled occupation (O'Connor 1984; Van Slyke 2009:15)" while the swindler was seen as "a professional, male, slightly older than the violent offender (in his thirties), married, and possessing a very good education" (O'Connor 1984; Van Slyke 2009:15). The violent offender was also characterized as "dangerous, vicious, non-intelligent, commits other crimes, immature, and inconsiderate" (O’Connor 1984; Van Slyke 2009:15) whereas the swindler was characterized as having the qualities of "intelligence, good manners, maturity, and consideration for others (O’Connor 1984; Van Slyke 2009:15)". Rosoff (1989) looked at the interaction of social status and punitiveness relative to offense seriousness and found that a higher status was linked to harsher judgments of guiltiness but decreased judgments of legal sentencing. Finally, Heumann (2005) in a qualitative study found that respondents perceived that certain professions like those of a doctor, lawyer, or teacher bring with them certain assumed levels of trust. Perceptions of white-collar criminals then are different than those of common or more traditional criminals, and these perceptions have real implications for sentencing. 


\section{White-Collar Criminals and Sentencing Considerations}

Perceptions are very important for sentencing considerations, factor into sentencing requirements, and are also a reflection of normative values in general (Naso 2011; Podgor 2007; Stylianou 2003). Perceptions have to do with the formation of a criminal identity and how people perceive of good and bad people (Tsoudis 2000). Those who are negatively perceived of have a particular identity that brings with it negative perceptions of how that person will act and what they deserve because of their negative identity when they do negative acts (Tsoudis 2000). Identity judgments about offenders based on a perceived criminal identity can affect sentencing decisions (Tsoudis and Smith-Lovin 1998). While there has been much work done on perceptions of criminals in general, little work has been done specifically looking at how people perceive of white-collar criminals and their particular identity relative to their occupation.

Sentencing of white-collar criminal offenders has shifted with the change in perceptions of them over time (Benson and Walker 1988; Cullen, Fisher, and Appelgate 2000; Cullen et. al 2008; Wheeler, Weisburd, and Bode 1982; Weiss 2007). While previous punishments may have been seen as too lenient, more recent proscribed punishments have been termed by some as draconian (Podgor 2007;). Punishment for white-collar crimes in the early 1900's into the mid 1990's were not very serious, and are even questionable as to their deterrent effect on crime. For the most part punishments were both monetary and civil, and in many instances did not even match or exceed the gains made from their illegality (Ermann and Lundman 2002). Cohen (1989) looked at the 1989 Sentencing Commission and found that while the Commission did fine two corporations more than $\$ 500,000$, the average fine was $\$ 141,000$. To put this amount into perspective, Ermann and Lundman (2002) based their calculation on what the fine of $\$ 141,000$ would mean to a small corporation with annual sales of $\$ 600$ million (about one tenth of Apple 
computer sales in 1999). They calculated that number and corresponded it the equivalent of a person earning $\$ 35,000$ per a year, finding that a small corporation that incurs the average fine of $\$ 141,000$ is essentially the same as someone who earns $\$ 35,000$ a year being fined $\$ 8$ (Ermann and Lundman 2002). Van Slyke (2009) alludes to the idea that more recent harsh sentences of white-collar offenders are meted out for show, and that they are more of an aberration than an accurate representation of typical prosecutions of white-collar offenders. Van Slyke (2009) characterizes sentencing practices, by pointing out the fact the two of the more infamous whitecollar offenders, Micheal Milken and Charles Keating, only served a small portion of their sentences for their egregious crimes. Milken was able to take investors for $\$ 10$ billion and only served 22 months of a 10-year sentence while Keating, who defrauded investors of $\$ 250$ million, spent less than 5 years in prison (Van Slyke 2009).

Sentencing decisions are supposed to be made in regard to the dangerousness of the offender and the seriousness of their offense and take into account only legally-relevant factors such as weapon use and the criminal history of the offender (Blumstein et al. 1983; Dilks, McGrimmon, and Thye 2011). However, from the criminology literature we know that extra-legal factors such as age, race, sex, level of education, etc. also impact, sometimes significantly, sentencing decisions (Dilks et al. 2011; Kramer and Steffensmeier 1993; Kramer and Ulmer 1996; Spohn 1995; Steffensmeier, Kramer, and Streifel 1993). Occupational status is a particularly relevant extra-legal factor in the case of white-collar crime but one that has not been explored as deeply as factors such as race, age and gender. Studies have been done that look at the relationship between employment and sentencing, but this is not the same as looking at the role of occupation in sentencing considerations. Unemployed individuals typically receive harsher sentences than employed individuals (Nobiling, Spohn, and DeLone 1998). However being employed and being 
sentenced for a crime is different than being employed and sentenced for a crime that was committed by using your occupation to do so. So then, while studies have looked at sentencing relevant to employment and unemployment these studies do not consider the actual role occupation in sentencing considerations. There is a gap then in the criminological literature concerning the link between occupation and sentencing in general, but looking at this relationship is particularly important for white-collar crimes since these are crime that are often conducted through the access to funds and resources that individuals have as part of their occupations. After reviewing the literature and relevant multiple theoretical and empirical studies that do exist, there are none to my knowledge that look specifically at how the occupational status of the white-collar criminal affects perceptions of white-collar crime and criminals.

\section{THEORETICAL FraMEWORK}

White-collar crime and street crime are clearly different, and people think of them as different. Rather than continuing to apply street crime theories to the study of white-collar crime, I argue that it makes more sense to use a theory about occupational status and perceptions of individuals based on their occupations to study white-collar crime. In order to gauge perceptions of white-collar crime and white-collar criminals, it is necessary to look at the role that status, particularly occupational status, plays in forming perceptions of white-collar crime. Therefore, I employ Status Characteristics Theory (SCT), a structural social psychological theory that links perceptions to observable status characteristics. SCT explains how particular traits and behaviors are inferred from an individual's race, age, sex, education, and occupational status. These inferred traits form the basis of expectations relative to an individual's competencies, culpabilities, and morality. Applying the theoretical framework of SCT to perceptions of whitecollar crime and criminality allows for these perceptions to be assessed in relation to the crime 
itself, morality, and the occupational prestige associated with a particular occupation. This represents a significant extension of previous work in the literature on perceptions of whitecollar crime, which typically assesses perceptions of crime comparatively, and not in relation to the actor themselves or their presumed status because of their occupation. The application of structural social psychological theory to understand perceptions of white-collar crime also expands the scope of SCT, which should prove to be an important contribution to the growth of social science.

\section{Status Characteristics Theory: Status, Expectations, and Diffuse Status Characteristics}

Status Characteristics Theory falls under the larger theory of expectations states. Expectations States Theory looks at how expectations form within groups for both other members of the group and self, in the context of a group activity or task (Berger, Cohen, and Zelditch 1972; Berger, Conner, and Fisek 1974; Berger, Zelditch, and Wagner 1985). These expectations are formed on the basis of group interaction and serve as "beliefs predictive of how an individual will perform or behave in general social situations or at specific tasks" (Dilks et al. 2011:8; Humphreys and Berger 1981). These beliefs about performance and behavior also include certain behavioral and moral expectations (Berger, Rosenholtz, and Zelditch 1980; Humphreys and Berger 1981).

Status Characteristics Theory extends upon these expectations and creates a deeper understanding and investigation of the attributes that are connected to specific expectations for behavior. Specifically, SCT connects culturally specified beliefs about social categories such as race and gender to expectations of an individual's general and specific behavior, in addition to perceptions of morality (Berger et al. 1972, 1974, 1985; Balkwell 1991; Dilks et al. 2011; Ridgeway, Berger, and Smith 1985). These expectations then ultimately determine one's 
position in an observable power and prestige hierarchy (Dilks et al. 2011; Balkwell 1991; Beger et al. 1972, 1974, 1985; Ridgeway et al. 1985). Certain characteristics on which individuals base beliefs and expectations become evident in group interactions, and under SCT are termed status characteristics (Berger and Webster 1986). One particular attribute or characteristic relative to expectations is a diffuse status characteristic. A diffuse status characteristic is one that is directly attributable to an individual based on meeting certain conditions and having certain characteristics. A diffuse status characteristic necessitates that for a particular characteristic it must (1) have multiple states that are differentially evaluated; (2) have specific expectations for each of those states; and (3) have general expectations for each of those states (Berger and Webster 1986).

Take for example the idea of gender acting as a diffuse status characteristic. Gender can be conceived of as a diffuse status characteristic in a population, because: (1) There are distinct social advantages and disadvantages associated with each of its particular states, with being male as being the presumed advantageous state; (2) There are specific skills and abilities associated with being male verses being female, such as the presumption that males are more competent in specific tasks like sports or quantitative reasoning; (3) There are also general expectations that males will be better or more capable at a large range of tasks, for instance the overall presumption based on the state of being male that males are more intelligent or more rational than females (Berger and Webster, 1986; Webster, Hysom, and Fullmer 1998).

Diffuse status characteristic states bring with them certain moral and performance expectations, which ultimately lead to the creation of a social hierarchy and intragroup inequalities. High status individuals, those considered in the advantageous state of a diffuse status characteristic, are considered to have higher levels of morality and ability compared to 
those in the less advantageous group. Performance expectations are created when a diffuse status characteristic becomes salient within a group, and individuals treat each other in the group based on the ideas they have formed relative to competencies and abilities (Webster et al. 1998).

SCT can be usefully leveraged to examine how the diffuse status characteristic of occupation acts in relation to people's perceptions of white-collar crime and white-collar criminals. Conceiving of occupational status as a diffuse characteristic in the context of committing a white-collar crime will allow for an adequate investigation of the role that high and low occupational prestige plays in perceptions of white-collar criminality. It is easily illustrated that occupation acts as a diffuse status characteristic. First, there are differentially evaluated states of occupation. A hierarchical ranking in society has been affirmed and reaffirmed through both longitudinal and cross-cultural studies that provide empirical evidence that occupations are ranked (Glenn 1975; Hodge and Rossi 1978; Marsh 1971; Nakao and Treas 1994). Occupations hold different amounts of prestige in accordance with their ranking. Such prestige is not naturally inherent in an occupation, but is rather socially given to such positions. It is human nature to value one thing over another and the evaluations that we give hold a moral component (Parsons 1954; Shils 1968; Treiman 1977; Veblin, 1919;). The evaluations are not limited simply to ones concerning taste or preference, but rather the morality component of the evaluation actually is judging the worthiness of one thing over another. These types of comparisons that factor in differences of worthiness then bring with them or reflect the shared norms and values found in the society from which the amount of prestige is judged (Parsons 1954; Shils 1968; Treiman 1977; Veblin, 1919;). As such we judge one occupation as more worthy than another, which results in a higher amount of prestige being accorded to those occupations we deem as more worthy in comparison to others (Treiman 1977). We trust those in higher occupational 
prestige positions to perform relevant tasks competently and morally because of the occupation that they hold and the prestige associated with it. For instance, a doctor is presumed to have a higher occupational prestige than a nurse.

Second, there are specific skills and abilities associated with being in a highly prestigious occupation along with more general competencies as compared to those associated with a low prestige occupation. Different occupations necessitate different amounts of "knowledge, training, or talent required for their performance" (Treiman 1977; 13). At the same time different occupations are given higher amounts of prestige or thought of as jobs that require more headwork than manual labor jobs or unskilled or semiskilled jobs (Treiman 1977). For instance, it is presumed that doctors who are high in occupational prestige have greater general competencies compared to nurses who occupy a lower occupational prestige status (Hodge, Siegel, and Rossi 1964; Miller 1991, pp. 341-351; Nakao and Treas 1994; Treiman 1977). In addition, doctors are presumed to have specific skills and abilities based on their occupation that differentiate them from nurses such as being able to prescribe medicine or perform surgeries (Treiman 1977; Webster et al. 1998).

\section{A Model of Status, Morality, and Perception of White-Collar Crime and Criminals}

As already discussed, SCT recognizes that individuals use status attributes to form expectations and infer and predict behaviors, competencies, and morality based on the state of a characteristic that another individual occupies. I argue that a person's occupational status influences others' perceptions of them as a white-collar criminal. Occupation plays a significant role in the muddied waters of perceptions of white-collar criminals in that a white-collar criminal is not a stereotypical criminal. White-collar criminals for the most part are in positions of power and occupy highly prestigious occupations such as CEO, doctor, or lawyer. These occupational 
statuses then influence our perceptions of white-collar criminals leading to differential perceptions and possibility punishments than those received by more traditional criminals, street criminals, and property offenders. Understanding the degree to which the occupation of the offender, and their occupational status matters, in the context of a crime is extremely important in understanding perceptions of white-collar crime.

SCT holds that high status individuals are expected to have higher levels of morality compared to low status individuals (Berger et al. 1980; Humphreys and Berger 1981). Thus, higher status individuals should be perceived as more likely to act morally, and any evidence of immoral acts done by higher status individuals would be perceived of as non-normal or anomalous. Therefore, I argue that high status occupations can assuage perceptions of crime severity and offender dangerousness (i.e., how 'criminal' an offender is), such that because of a person's occupation there is either a greater or lesser perception of offender dangerousness as well as a greater or lesser perception of severity associated with a particular crime.

More occupational prestige should result in lowered perceptions of dangerousness and severity, possibly explaining why white-collar criminals are not perceived as an imminent social threat. Occupationally high status, white-collar criminals should be perceived of as being more likely to act in moral ways. Occupationally low status individuals should be perceived as less likely to act in moral ways. Following then the logic of SCT as applied to perceptions of the dangerousness of white-collar criminals, the following hypotheses will be tested:

H1a: Criminals from more prestigious occupational positions will be considered less criminal.

Legal guidelines are driven by people's perceptions, and include sentencing considerations. Sentencing guidelines are supposed to be determined by judgments of the 
offender's dangerousness and the seriousness of the offense (Blumstein et al. 1983; Dilks et al. 2011). Logically then if an offender is perceived of as more dangerous and their offense is perceived of as more severe they are viewed as more criminalistic, and as such should receive a harsher punishment (Dilks et al. 2011). Perceptions of dangerousness and sentencing are linked and if a criminal is perceived of as more or less dangerous based on certain attributes then they should receive differential sentencing considerations because of that attribute and how it relates to perceptions of offender dangerousness. It is argued, following the logic of SCT, that because a criminal is from a more prestigious occupational position that status considerations based on occupation will lessen perceptions of the offenders criminality and as such result in a lesser proscribed punishment.

H1b: Criminals from more prestigious occupational positions will be punished less harshly than those from lower status occupational positions.

I also assess whether or not such status effects interact with the seriousness of the crime. As mentioned above offense seriousness also affects sentencing decisions (Dilks et a. 2011). So then the seriousness of the crime in addition to the status and perceptions of the criminal must be considered as well. Specifically, does the seriousness of the crime outweigh status considerations and warrant harsher punishments and higher levels of culpability for even those high status offenders?

H2: As crime seriousness increases, the impact of status on perceptions and sentencing decreases.

\section{METHODS}

\section{Experimental Design}


To test my hypotheses, vignettes were created in which white-collar crimes of comparative and differing levels of seriousness and societal damages are committed by criminals who differ in their occupational status. Each vignette included a series of close-ended questions from which perceptions of white-collar criminals in relation to the diffuse status characteristic of occupational status can be gleaned. To examine the general effects of status on perceptions of white-collar criminals (H1a) and the role of status relative to punishment (H1b), a two-condition completely randomized experiment in which the offender occupies either a high or low status was designed (Experiment 1).

\section{Figure 1: Experiment 1}

\begin{tabular}{|c|c|}
$\begin{array}{c}\text { Offender Status } \\
\text { High }\end{array}$ & \\
\cline { 2 - 2 } Low & Condition 1 \\
\cline { 2 - 2 } & Condition 2 \\
\hline
\end{tabular}

Tests of the secondary hypothesis regarding interactions between status and crime severity (H2) were assessed through a $2 \times 2$ factorial vignette in which the offender's status varies between high and low status and crime severity corresponds with a high or low level of seriousness (Experiment 2).

Figure 2: Experiment 2

\section{Seriousness}

\begin{tabular}{llll|l|} 
& \multicolumn{2}{c}{ Seriousness } \\
\cline { 3 - 4 } Offender Status & High & \multicolumn{1}{c}{ Low } \\
\cline { 3 - 4 } & High & Condition 1 & Condition 2 \\
\cline { 3 - 4 } & Low & Condition 3 & Condition 4 \\
\cline { 3 - 4 } & & &
\end{tabular}


The vignettes describe cases of overbilling, a common white-collar crime. ${ }^{1}$ The high status vignette contains an instance of overbilling by a lawyer who occupies a higher occupational prestige position than the lower status position included in the low status vignette, which is that of a billing clerk. The only status manipulations built into vignettes are relative to occupation. All offenders are presented as male, and participants are not given indications of age, race, or education. The vignettes in Experiment 1only manipulate the occupational status of the offender and keep constant the severity of the crime. In contrast, Experiment 2 contains manipulations of both the offender's occupational status and the severity of the crime. The vignettes for each condition in the final test can be found below, while all the vignettes, including those from a pretest, can be found in Appendix C.

\section{Experiment 1:}

Condition 1: Robert Sullivan is a lawyer who works for a large law firm in a major city. Robert overbills his clients for hours during which he did not work on their case. As a result, Robert's firm earns an extra $\$ 10,000$ a year.

Condition 2: Andrew Smith is a billing clerk for a construction company. Andrew overcharges clients for hours that construction crews did not work. Andrew's company profits $\$ 10,000$ a year from overbilling clients.

\section{Experiment 2:}

Condition 1: Robert Sullivan is a lawyer who works for a large law firm in a major city. Robert overbills his clients for hours during which he did not work on their case. As a result, Robert's firm earns an extra $\$ 100,000$ a year.

Condition 2: Robert Sullivan is a lawyer who works for a large law firm in a major city. Robert overbills his clients for hours during which he did not work on their case. As a result, Robert's firm earns an extra $\$ 10,000$ a year.

\footnotetext{
${ }^{1}$ A pretest of vignettes used various types of white-collar crimes including medical fraud, overbilling, embezzlement, and a Ponzi scheme. t-tests revealed that the largest status and crime severity effects were found for the overbilling vignette.
} 
Condition 3: Andrew Smith is a billing clerk for a construction company. Andrew overcharges clients for hours that construction crews did not work. Andrew's company profits $\$ 100,000$ a year from overbilling clients.

Condition 4: Andrew Smith is a billing clerk for a construction company. Andrew overcharges clients for hours that construction crews did not work. Andrew's company profits $\$ 10,000$ a year from overbilling clients.

\section{Subjects}

Vignettes were randomized and distributed to 394 undergraduate students (197 males and 165 females) in introductory sociology classes at a large mid-Atlantic university. Students were told that the voluntary study they were being invited to take part in was concerned with their reactions to an instance of white-collar crime. Students were asked to read about the occurrence of a white-collar crime and to then answer questions about their perceptions of both the offender and the offense as well as assign a sentence to the offender. The questionnaire also asked basic demographic information such as gender, race, and family income. The vignettes and surveys took between 10 and 15 minutes to complete, and the students were only asked to respond to one vignette each.

As can be seen in Table 1 below, respondents are overwhelmingly 21 years old or younger $(87.99 \%)$, as well as white $(78.65 \%)$. The majority of respondents $(91.43 \%)$ are in their first three years of their undergraduate education, with $80 \%$ being in their first two years of school and $57.92 \%$ being in their first year. Respondents are fairly well distributed amongst majors, with $94.8 \%$ having a high school GPA of 2.50 or greater and $82.74 \%$ having a college GPA of 2.50 or higher. Over half $(52.41 \%)$ of respondents indicate that their parents estimated yearly income is $\$ 80,000$ or greater.

Table 1: Descriptive Statistics for Participants

\begin{tabular}{|l|c|c|c|}
\hline Variable & $\%($ Frequency) & $\begin{array}{c}\% \\
\text { (Frequency) }\end{array}$ & $\begin{array}{c}\% \\
\text { (Frequency) }\end{array}$ \\
\hline Age: & Experiment 1 and 2 & Experiment 1 & Experiment 2 \\
\hline
\end{tabular}




\begin{tabular}{|c|c|c|c|}
\hline & $(\mathrm{N}=381)$ & $(\mathrm{N}=123)$ & $(\mathrm{N}=260)$ \\
\hline 19 or younger & $\begin{array}{l}65.54 \\
(251)\end{array}$ & $65.85(81)$ & $\begin{array}{l}65.38 \\
(170)\end{array}$ \\
\hline $20-21$ & $\begin{array}{c}22.45 \\
(86)\end{array}$ & $\begin{array}{c}23.58 \\
(29)\end{array}$ & $\begin{array}{c}21.92 \\
(57)\end{array}$ \\
\hline $22-23$ & $\begin{array}{l}3.59 \\
(13)\end{array}$ & $\begin{array}{c}4.88 \\
(6)\end{array}$ & $\begin{array}{c}2.69 \\
(7)\end{array}$ \\
\hline $24-25$ & $\begin{array}{c}1.83 \\
(7)\end{array}$ & $\begin{array}{c}0 \\
(0) \\
\end{array}$ & $\begin{array}{c}2.69 \\
(7)\end{array}$ \\
\hline $26-27$ & $\begin{array}{c}1.83 \\
(7)\end{array}$ & $\begin{array}{c}1.63 \\
(2)\end{array}$ & $\begin{array}{c}1.92 \\
(5)\end{array}$ \\
\hline $28-29$ & $\begin{array}{l}2.87 \\
(11)\end{array}$ & $\begin{array}{c}2.44 \\
(3)\end{array}$ & $\begin{array}{c}3.08 \\
(8)\end{array}$ \\
\hline 30 or Older & $\begin{array}{c}1.57 \\
(6)\end{array}$ & $\begin{array}{c}1.63 \\
(2)\end{array}$ & $\begin{array}{c}1.54 \\
(4)\end{array}$ \\
\hline Race/Ethnicity: & $\begin{array}{c}\text { Experiment } 1 \text { and } 2 \\
(\mathrm{~N}=384)\end{array}$ & $\begin{array}{l}\text { Experiment } 1 \\
(\mathrm{~N}=123)\end{array}$ & $\begin{array}{c}\text { Experiment } 2 \\
(\mathrm{~N}=261)\end{array}$ \\
\hline Hispanic or Latino & $\begin{array}{l}5.99 \\
(23)\end{array}$ & $\begin{array}{c}4.88 \\
(6)\end{array}$ & $\begin{array}{l}6.51 \\
(17)\end{array}$ \\
\hline $\begin{array}{c}\text { American Indian or } \\
\text { Alaska Native }\end{array}$ & $\begin{array}{c}1.04 \\
(4)\end{array}$ & $\begin{array}{c}2.44 \\
(3)\end{array}$ & $\begin{array}{c}0.38 \\
(1)\end{array}$ \\
\hline Asian & $\begin{array}{l}2.60 \\
(10)\end{array}$ & $\begin{array}{c}2.44 \\
(3)\end{array}$ & $\begin{array}{c}2.68 \\
(7)\end{array}$ \\
\hline $\begin{array}{l}\text { Black or African } \\
\text { American }\end{array}$ & $\begin{array}{l}5.12 \\
(20)\end{array}$ & $\begin{array}{c}5.69 \\
(7)\end{array}$ & $\begin{array}{l}4.98 \\
(13)\end{array}$ \\
\hline $\begin{array}{l}\text { Native Hawaiian or } \\
\text { Pacific Islander }\end{array}$ & $\begin{array}{l}1.30 \\
(5)\end{array}$ & $\begin{array}{c}1.63 \\
(2)\end{array}$ & $\begin{array}{l}1.15 \\
(3)\end{array}$ \\
\hline White & $\begin{array}{l}78.65 \\
(302)\end{array}$ & $\begin{array}{c}77.24 \\
(95)\end{array}$ & $\begin{array}{l}79.31 \\
(207)\end{array}$ \\
\hline Other & $\begin{array}{c}2.34 \\
(9)\end{array}$ & $\begin{array}{c}1.63 \\
(2)\end{array}$ & $\begin{array}{c}2.68 \\
(7)\end{array}$ \\
\hline More than one race & $\begin{array}{l}2.86 \\
(11)\end{array}$ & $\begin{array}{c}4.07 \\
(5)\end{array}$ & $\begin{array}{c}2.30 \\
(6)\end{array}$ \\
\hline $\begin{array}{l}\text { Current Year in } \\
\text { School: }\end{array}$ & $\begin{array}{c}\text { Experiment } 1 \text { and } 2 \\
(\mathrm{~N}=383)\end{array}$ & $\begin{array}{l}\text { Experiment } 1 \\
(\mathrm{~N}=123)\end{array}$ & $\begin{array}{c}\text { Experiment } 2 \\
(\mathrm{~N}=262)\end{array}$ \\
\hline 1 & $\begin{array}{l}57.92 \\
(223)\end{array}$ & $\begin{array}{l}59.35 \\
(73)\end{array}$ & $\begin{array}{l}57.25 \\
(150)\end{array}$ \\
\hline 2 & $\begin{array}{c}22.08 \\
(85)\end{array}$ & $\begin{array}{c}18.70 \\
(23)\end{array}$ & $\begin{array}{c}23.66 \\
(62)\end{array}$ \\
\hline 3 & $\begin{array}{c}11.43 \\
(44)\end{array}$ & $\begin{array}{c}12.20 \\
(15)\end{array}$ & $\begin{array}{c}11.07 \\
(29)\end{array}$ \\
\hline 4 & $\begin{array}{l}5.19 \\
(20)\end{array}$ & $\begin{array}{c}4.88 \\
(6)\end{array}$ & $\begin{array}{l}5.34 \\
(14)\end{array}$ \\
\hline 5 & $\begin{array}{c}1.56 \\
(6)\end{array}$ & $\begin{array}{l}3.25 \\
(4)\end{array}$ & $\begin{array}{c}0.76 \\
(2)\end{array}$ \\
\hline
\end{tabular}




\begin{tabular}{|c|c|c|c|}
\hline 6 & $\begin{array}{c}1.30 \\
(5)\end{array}$ & $\begin{array}{c}0.81 \\
(1)\end{array}$ & $\begin{array}{l}1.53 \\
(14)\end{array}$ \\
\hline Major: & $\begin{array}{c}\text { Experiment } 1 \text { and } 2 \\
(N=382)\end{array}$ & $\begin{array}{l}\text { Experiment } 1 \\
(\mathrm{~N}=124)\end{array}$ & $\begin{array}{l}\text { Experiment } 2 \\
(\mathrm{~N}=259)\end{array}$ \\
\hline Undecided & $\begin{array}{l}8.36 \\
(32)\end{array}$ & $\begin{array}{c}12.10 \\
(15)\end{array}$ & $\begin{array}{l}6.56 \\
(17)\end{array}$ \\
\hline $\begin{array}{l}\text { Social/Behavioral } \\
\text { Sciences }\end{array}$ & $\begin{array}{c}13.32 \\
(51)\end{array}$ & $\begin{array}{c}17.74 \\
(22)\end{array}$ & $\begin{array}{l}11.70 \\
(29)\end{array}$ \\
\hline Humanities & $\begin{array}{l}7.83 \\
(30)\end{array}$ & $\begin{array}{c}6.45 \\
(8)\end{array}$ & $\begin{array}{l}8.49 \\
(22)\end{array}$ \\
\hline $\begin{array}{c}\text { Engineering, } \\
\text { Computer Science }\end{array}$ & $\begin{array}{c}15.14 \\
(58)\end{array}$ & $\begin{array}{l}20.16 \\
(25)\end{array}$ & $\begin{array}{c}12.74 \\
(33)\end{array}$ \\
\hline Education & $\begin{array}{c}2.35 \\
(9)\end{array}$ & $\begin{array}{c}3.23 \\
(4)\end{array}$ & $\begin{array}{c}1.93 \\
(5)\end{array}$ \\
\hline $\begin{array}{l}\text { Natural/Physical } \\
\text { Sciences }\end{array}$ & $\begin{array}{l}26.11 \\
(100)\end{array}$ & $\begin{array}{l}20.97 \\
(26)\end{array}$ & $\begin{array}{l}28.57 \\
(74)\end{array}$ \\
\hline Business & $\begin{array}{c}14.88 \\
(57)\end{array}$ & $\begin{array}{l}8.06 \\
(10)\end{array}$ & $\begin{array}{c}18.15 \\
(47)\end{array}$ \\
\hline Other & $\begin{array}{c}11.75 \\
(45)\end{array}$ & $\begin{array}{c}10.48 \\
(13)\end{array}$ & $\begin{array}{c}12.36 \\
(32)\end{array}$ \\
\hline Sex: & $\begin{array}{c}\text { Experiment } 1 \text { and } 2 \\
(N=362)\end{array}$ & $\begin{array}{l}\text { Experiment } 1 \\
(\mathrm{~N}=123)\end{array}$ & $\begin{array}{l}\text { Experiment } 2 \\
(\mathrm{~N}=257)\end{array}$ \\
\hline Male & $\begin{array}{l}51.84 \\
(197)\end{array}$ & $\begin{array}{c}56.91 \\
(70)\end{array}$ & $\begin{array}{l}49.42 \\
(127)\end{array}$ \\
\hline Female & $\begin{array}{l}43.42 \\
(165)\end{array}$ & $\begin{array}{c}38.21 \\
(47)\end{array}$ & $\begin{array}{l}45.91 \\
(118)\end{array}$ \\
\hline High School GPA: & $\begin{array}{c}\text { Experiment } 1 \text { and } 2 \\
(N=363)\end{array}$ & $\begin{array}{l}\text { Experiment } 1 \\
(\mathrm{~N}=116)\end{array}$ & $\begin{array}{l}\text { Experiment } 2 \\
(\mathrm{~N}=249)\end{array}$ \\
\hline $0-.99$ & $\begin{array}{c}0 \\
(0)\end{array}$ & $\begin{array}{c}0 \\
(0)\end{array}$ & $\begin{array}{c}0 \\
(0)\end{array}$ \\
\hline $1.00-1.99$ & $\begin{array}{c}1.37 \\
(5)\end{array}$ & $\begin{array}{c}0 \\
(0)\end{array}$ & $\begin{array}{c}2.01 \\
(5)\end{array}$ \\
\hline $2.00-2.49$ & $\begin{array}{l}3.29 \\
(12)\end{array}$ & $\begin{array}{c}2.59 \\
(3)\end{array}$ & $\begin{array}{c}3.61 \\
(9)\end{array}$ \\
\hline $2.50-2.99$ & $\begin{array}{c}10.41 \\
(38)\end{array}$ & $\begin{array}{r}12.07 \\
(14)\end{array}$ & $\begin{array}{l}9.64 \\
(24)\end{array}$ \\
\hline $3.00-3.49$ & $\begin{array}{l}31.51 \\
(115)\end{array}$ & $\begin{array}{c}28.45 \\
(33)\end{array}$ & $\begin{array}{c}32.93 \\
(82)\end{array}$ \\
\hline 3.50 or greater & $\begin{array}{l}52.88 \\
(193)\end{array}$ & $\begin{array}{c}56.90 \\
(66)\end{array}$ & $\begin{array}{l}51.00 \\
(127)\end{array}$ \\
\hline College GPA: & $\begin{array}{c}\text { Experiment } 1 \text { and } 2 \\
(\mathrm{~N}=359)\end{array}$ & $\begin{array}{l}\text { Experiment } 1 \\
(\mathrm{~N}=119)\end{array}$ & $\begin{array}{c}\text { Experiment } 2 \\
(\mathrm{~N}=246)\end{array}$ \\
\hline $0-.99$ & $\begin{array}{l}1.37 \\
(5)\end{array}$ & $\begin{array}{c}0.84 \\
(1)\end{array}$ & $\begin{array}{c}1.63 \\
(4)\end{array}$ \\
\hline $1.00-1.99$ & $\begin{array}{l}3.56 \\
(13)\end{array}$ & $\begin{array}{c}5.88 \\
(1)\end{array}$ & $\begin{array}{c}2.44 \\
(6)\end{array}$ \\
\hline
\end{tabular}




\begin{tabular}{|c|c|c|c|}
\hline $2.00-2.49$ & $\begin{array}{c}10.68 \\
(39)\end{array}$ & $\begin{array}{c}10.92 \\
(13)\end{array}$ & $\begin{array}{c}10.57 \\
(26)\end{array}$ \\
\hline $2.50-2.99$ & $\begin{array}{c}21.92 \\
(80)\end{array}$ & $\begin{array}{c}25.21 \\
(30)\end{array}$ & $\begin{array}{c}20.33 \\
(50)\end{array}$ \\
\hline $3.00-3.49$ & $\begin{array}{l}30.41 \\
(111)\end{array}$ & $\begin{array}{c}27.73 \\
(33)\end{array}$ & $\begin{array}{l}31.71 \\
(78)\end{array}$ \\
\hline 3.50 or greater & $\begin{array}{l}30.41 \\
(111)\end{array}$ & $\begin{array}{c}26.89 \\
(32)\end{array}$ & $\begin{array}{c}32.11 \\
(79)\end{array}$ \\
\hline $\begin{array}{l}\text { Parents' estimated } \\
\text { yearly income: }\end{array}$ & $\begin{array}{c}\text { Experiment } 1 \text { and } 2 \\
(\mathrm{~N}=353)\end{array}$ & $\begin{array}{l}\text { Experiment } 1 \\
(\mathrm{~N}=116)\end{array}$ & $\begin{array}{c}\text { Experiment } 2 \\
(\mathrm{~N}=237)\end{array}$ \\
\hline$\$ 0-9,999$ & $\begin{array}{c}1.70 \\
(6)\end{array}$ & $\begin{array}{c}3.45 \\
(4)\end{array}$ & $\begin{array}{c}0.84 \\
(2)\end{array}$ \\
\hline$\$ 10,000-19,999$ & $\begin{array}{l}3.12 \\
(11)\end{array}$ & $\begin{array}{c}3.45 \\
(4)\end{array}$ & $\begin{array}{c}2.95 \\
(7)\end{array}$ \\
\hline$\$ 20,000-29,999$ & $\begin{array}{l}3.40 \\
(12)\end{array}$ & $\begin{array}{c}2.59 \\
(3)\end{array}$ & $\begin{array}{c}3.80 \\
(9)\end{array}$ \\
\hline$\$ 30,000-39,999$ & $\begin{array}{l}5.10 \\
(18)\end{array}$ & $\begin{array}{c}5.17 \\
(6)\end{array}$ & $\begin{array}{l}5.06 \\
(12)\end{array}$ \\
\hline$\$ 40,000-49,999$ & $\begin{array}{l}6.23 \\
(22)\end{array}$ & $\begin{array}{c}3.45 \\
(4)\end{array}$ & $\begin{array}{l}7.59 \\
(18)\end{array}$ \\
\hline$\$ 50,000-59,999$ & $\begin{array}{l}8.78 \\
(31)\end{array}$ & $\begin{array}{c}6.03 \\
(7)\end{array}$ & $\begin{array}{c}10.13 \\
(24)\end{array}$ \\
\hline$\$ 60,000-69,999$ & $\begin{array}{c}10.48 \\
(37)\end{array}$ & $\begin{array}{c}12.07 \\
(14)\end{array}$ & $\begin{array}{l}9.70 \\
(23)\end{array}$ \\
\hline$\$ 70,000-79,999$ & $\begin{array}{l}8.78 \\
(31)\end{array}$ & $\begin{array}{c}6.90 \\
(8)\end{array}$ & $\begin{array}{l}9.70 \\
(23)\end{array}$ \\
\hline$\$ 80,000-89,999$ & $\begin{array}{c}10.20 \\
(36)\end{array}$ & $\begin{array}{c}12.93 \\
(15)\end{array}$ & $\begin{array}{l}8.86 \\
(21)\end{array}$ \\
\hline$\$ 90,000$ or greater & $\begin{array}{l}42.21 \\
(149)\end{array}$ & $\begin{array}{r}43.97 \\
(51)\end{array}$ & $\begin{array}{l}41.35 \\
(98)\end{array}$ \\
\hline
\end{tabular}

Notes: $\mathrm{N}$ is not equal for all variables, which may be explained for multiple reasons. Subjects were told that their participation was voluntary and that they could choose to answer or not answer questions. Answers were also made on Scantron sheets, which if not filled out properly would not be recorded into the database. Lastly the surveys were printed on both sides of the paper, and though respondents were reminded to not forget to fill out questions on back page of last sheet, many participants neglected to fill out the questions found on the backside of the last page.

\section{Measurements}

The questionnaire included with the vignettes is designed to measure the concepts of: status, crime severity, perceptions of the offender, and sentencing. In order to actually measure these variables, survey items were constructed and grouped so that overall contributing factors 
could be considered. All of the questions utilize a ten point scale with high and low anchor points.

In order to measure the offender's status, participants were asked six questions: 1) In your opinion, how much status does the offender generally possess? 2) In your opinion, how much prestige does the offender generally possess? 3) In your opinion, how generally honorable is the offender? 4) In your opinion, how generally moral is the offender? 5) In your opinion, how generally competent is the offender? 6) In your opinion, how generally intelligent is the offender? For all questions, higher numbers indicate higher levels of status and lower numbers indicate lower levels of status.

Crime severity was measured using eight items with "Not at all" or "Extremely" as anchor points. All crime severity questions focused on effects of the crime on the victims. Crime severity questions included: 1) Are you outraged by the crime against the victims? 2) Have victims suffered as a result of the crime? 3) Have victims suffered physically as a result of the crime? 4) Have victims suffered emotionally as a result of the crime? 5) Have victims suffered financially as a result of the crime? 6) Was the crime insulting against the victims? 7) Was the crime disrespectful to the victims? 8) Was the crime offensive to the victims? Again, higher numbers indicate a more severe crime, while lower levels indicate a less severe crime.

Perceptions of the offender were measured by using six items, the first four of which used "Not Likely" and "Not Often" or "Very Likely" and "Very Often" as anchor points. These questions included: 1) How likely is it that the offender will commit this crime in the future? 2) How often do you think the offender has committed this crime before? 3) How likely is it that the offender will commit a street crime in the future? 4) How likely is it that the offender generally obeys the law? Answers to the question of how likely it is that the offender generally obeys the 
law were reverse coded, such that a higher mean score on this measure meant that the individual was considered less criminal. The final two items used "Good, nice" and "Not blameworthy" or "Bad, awful" and "Very blameworthy" as anchor points. These questions included: 1) In your opinion, what the offender did was... 2) In your opinion, how generally blameworthy is the offender?

Sentencing was measured via three items on a ten point scale. Sentencing items included: 1) What sentence would you recommend? 2) What is the minimum sentence you would agree upon? 3) What is the maximum sentence you would agree upon? The scale included:

1) Misdemeanor fine, no prison term

2) Probation with no prison term

3) 5 Years with opportunity for parole

4) 10 Years with opportunity for parole

5) 15 Years with opportunity for parole

6) 20 Years with opportunity for parole

7) 25 Years with opportunity for parole

8) Life imprisonment with opportunity for parole

9) Life Imprisonment without parole

10) Death Penalty.

\section{RESULTS}

\section{Experiment 1}

\section{Manipulation Checks}

Manipulation checks using $t$-tests are used to determine whether respondents 1) correctly perceive the differences in offender status across experimental conditions and 2) did not perceive any differences in crime severity since the nature of the crime remained constant across conditions. Table 2 presents the results of the status manipulation checks. All variables, except intelligence, have higher means for the high status offender as compared to the low status offender. Furthermore, four of the six measures show statistically significant differences between 
high and low status conditions. Therefore, I confidently conclude that the vignette conditions successfully manipulated offender status in Experiment 1.

Table 2: Mean Ratings of Manipulated Status by Condition for Experiment 1

\begin{tabular}{|c|c|c|c|}
\hline Variable & $\begin{array}{c}\text { High Status } \\
\boldsymbol{N}=\mathbf{6 4}\end{array}$ & $\begin{array}{c}\text { Low Status } \\
\boldsymbol{N}=\mathbf{6 4}\end{array}$ & $\boldsymbol{t}$ \\
\hline \multirow{2}{*}{ Status } & $\begin{array}{c}7.2031 \\
(2.0014)\end{array}$ & $\begin{array}{c}6.1719 \\
(2.0123)\end{array}$ & $-2.9068^{* * *}$ \\
\hline \multirow{2}{*}{ Prestige } & $\begin{array}{c}6.4375 \\
(1.9990)\end{array}$ & $\begin{array}{c}5.6094 \\
(2.3273)\end{array}$ & $-2.1594^{* *}$ \\
\hline \multirow{2}{*}{ Honor } & $\begin{array}{c}3.4688 \\
(2.3229)\end{array}$ & $\begin{array}{c}2.8594 \\
(1.9507)\end{array}$ & $-1.6071^{*}$ \\
\hline \multirow{2}{*}{ Moral } & $\begin{array}{c}3.4062 \\
(2.3280)\end{array}$ & $\begin{array}{c}2.7188 \\
(1.7948)\end{array}$ & $-1.8710^{* *}$ \\
\hline \multirow{2}{*}{ Competent } & $\begin{array}{c}5.9219 \\
(2.5467)\end{array}$ & $\begin{array}{c}5.6032 \\
(2.3592)\end{array}$ & -.7313 \\
\hline \multirow{2}{*}{ Intelligent } & 7.2813 & $\begin{array}{c}7.3810 \\
(1.6107)\end{array}$ & .3438 \\
\hline
\end{tabular}

Notes: Standard deviations in parentheses

$*_{p}<.10$ (one-tailed test)

$* * p<.05$ (one-tailed test)

$* * * p<.01$ (one-tailed test)

Manipulation checks also compare the different conditions in Experiment 1 on crime severity. The participants in Experiment 1 were given crimes with the same level of severity of consequences and costs for that crime, therefore no significant differences are expected in the means of these measures. Table 3 shows the results of these manipulation checks and, as anticipated, none of the variables are statistically significant. Since the crimes participants responded to were equal in their levels of severity, and no level of statistical difference was found it is reasonable to conclude that manipulations of severity in Experiment 1 are successful.

Table 3: Mean Ratings of Manipulated Severity by Condition for Experiment 1

\begin{tabular}{|c|c|c|c|}
\hline Variable & $\begin{array}{c}\text { High Status } \\
\boldsymbol{N = 6 4}\end{array}$ & $\begin{array}{c}\text { Low Status } \\
\boldsymbol{N}=\mathbf{6 4}\end{array}$ & $\boldsymbol{t}$ \\
\hline \multirow{2}{*}{ Outraged } & 6.3281 & 6.4444 & \\
& $(2.2400)$ & $(1.8208)$ & .3208 \\
\hline \multirow{2}{*}{ Suffered } & 6.9062 & 6.9048 & -.0043 \\
\hline Suffered Physically & $(1.7792)$ & $(2.0846)$ & -1.2099 \\
\hline
\end{tabular}




\begin{tabular}{|c|c|c|c|}
\hline & $(2.1907)$ & $(2.2394)$ & .1821 \\
\hline Suffered Emotionally & $\begin{array}{c}5.9063 \\
(2.3348)\end{array}$ & $\begin{array}{c}5.9844 \\
(2.5166)\end{array}$ & .9735 \\
\hline Suffered Financially & $\begin{array}{c}8.3125 \\
(1.7717)\end{array}$ & $\begin{array}{c}8.6094 \\
(1.6773)\end{array}$ & 1.5793 \\
\hline Insulting & $\begin{array}{c}6.8125 \\
(2.3896)\end{array}$ & $\begin{array}{c}7.4375 \\
(2.0769)\end{array}$ & 1.2872 \\
\hline Disrespectful & $\begin{array}{c}8.25 \\
(2.1307)\end{array}$ & $\begin{array}{c}8.6875 \\
(1.6891)\end{array}$ & 1.0444 \\
\hline Offensive & $\begin{array}{c}7.3016 \\
(2.4993)\end{array}$ & $(1.7789)$ & \\
\hline
\end{tabular}

Notes: Standard deviations in parentheses

\section{Test of Hypotheses 1a and $1 b$}

Hypothesis 1a predicts that status, specifically occupational status, leads to a difference in perceptions of white-collar criminals. Table 4 presents the results of a series of $t$-tests that examine Hypothesis 1a for Experiment 1. The mean scores for the perception variables relative to high and low status differ on every variable with the low status offender always seen as more 'criminal,' as indicated by the higher mean scores. ${ }^{2}$ Furthermore, four of the six variables show statistically significant differences in perceptions. These results support Hypothesis 1a: High status offenders are perceived as less criminal than low status offenders.

Table 4: Tests of Hypothesis 1a for Experiment 1

\begin{tabular}{|c|c|c|c|}
\hline Variable & $\begin{array}{c}\text { High Status } \\
\mathbf{N = 6 4}\end{array}$ & $\begin{array}{c}\text { Low Status } \\
\mathbf{N = 6 4}\end{array}$ & $\boldsymbol{t}$ \\
\hline Likely Commit in & $\begin{array}{c}8.3906 \\
(1.9323)\end{array}$ & $\begin{array}{c}8.9686 \\
(1.4689)\end{array}$ & $1.9054^{* *}$ \\
Future & $\begin{array}{c}7.8281 \\
(1.9965)\end{array}$ & $\begin{array}{c}8.5313 \\
(1.8428)\end{array}$ & $2.0704 * *$ \\
\hline Committed Before & $\begin{array}{c}3.2344 \\
(1.9334)\end{array}$ & $\begin{array}{c}3.9206 \\
(1.8863)\end{array}$ & $2.0243^{* *}$ \\
\hline Street Crime Future & $\begin{array}{c}5.8594 \\
(2.3561)\end{array}$ & $\begin{array}{c}5.4762 \\
(1.8215)\end{array}$ & -1.0242 \\
\hline Obeys Law & $\begin{array}{c}8.125 \\
(1.8898)\end{array}$ & $\begin{array}{c}8.3594 \\
(1.3958)\end{array}$ & .7981 \\
\hline Offender Did & &
\end{tabular}

\footnotetext{
${ }^{2}$ The exception is the mean scores for Obeys Law. This variable is reverse-coded such that higher mean scores represent a less criminal identity. Note that the high status offender has a higher mean than the low status offender, which continues to support Hypothesis 1a.
} 


\begin{tabular}{|c|c|c|c|}
\hline Blameworthy & $\begin{array}{c}8.2969 \\
(1.9975)\end{array}$ & $\begin{array}{c}8.9219 \\
(1.7576)\end{array}$ & $1.8793^{*}$ \\
\hline
\end{tabular}

Notes: Standard deviations in parentheses. The variable Obeys Law is reverse coded such that a higher mean score indicates a less criminal perception. For the remaining variables, higher mean scores indicate a more criminal perception of the offender.

$* p<.10$ (one-tailed test)

$* * p<.05$ (one-tailed test)

$* * * p<.01$ (one-tailed test)

Tests of Hypothesis $1 \mathrm{~b}$ for Experiment 1 also utilize $t$-tests to compare sentencing variables for differing levels of occupational status. Hypothesis $1 \mathrm{~b}$ predicts that criminals from more prestigious occupational prestige positions will be punished less harshly than those from lower status positions. However, the results in Table 5 show that while all variables yield differences in mean scores, it is actually the higher status white-collar offender that receives a higher mean sentence on recommended sentence, minimum sentencing, and maximum sentencing. Furthermore, differences in mean scores on the measures for minimum and maximum sentence are significant. These results are opposite of that predicted by Hypothesis 1b: Subjects actually assigned more severe punishments to the high status offenders.

Table 5: Tests of Hypothesis $1 \mathrm{~b}$ for Experiment 1

\begin{tabular}{|c|c|c|c|}
\hline Variable & $\begin{array}{c}\text { High Status } \\
\boldsymbol{N}=\mathbf{6 4}\end{array}$ & $\begin{array}{c}\text { Low Status } \\
\boldsymbol{N}=\mathbf{6 4}\end{array}$ & $\boldsymbol{t}$ \\
\hline Recommended & $\begin{array}{c}3.4531 \\
(1.7083)\end{array}$ & $\begin{array}{c}3.125 \\
(1.442)\end{array}$ & -1.1742 \\
\hline Sentence & $\begin{array}{c}2.7344 \\
(1.3714)\end{array}$ & $\begin{array}{c}2.4219 \\
(1.1657)\end{array}$ & $-1.3890^{*}$ \\
\hline Minimum Sentence & $\begin{array}{c}4.5397 \\
(1.5640)\end{array}$ & $\begin{array}{c}4.1094 \\
(1.6914)\end{array}$ & $-1.4880^{*}$ \\
\hline Maximum Sentence & &
\end{tabular}

Notes: Standard deviations in parentheses.

${ }^{*} p<.10$ (one-tailed test)

$*_{* *} p<.05$ (one-tailed test)

$* * * p<.01$ (one-tailed test)

Although $t$-tests do not find the predicted differences in sentencing for high vs. low status offenders, this result does not necessarily negate Hypothesis 1b. According to SCT and the 
criminological research on sentencing, the link between status and sentencing is not assumed to be a direct one. Rather, it is argued that status affects perceptions of criminality and offender dangerousness which in turn affect sentencing. The previous $t$-tests do not assess this indirect link. In the next section, I employ structural equation modeling to more fully examine the implications that status-based perceptions have for the sentencing of white collar criminals.

\section{Structural Equation Modeling: Ancillary Test of Hypothesis $1 a$ and $1 b$}

A structural equation model (SEM), as illustrated in Figure 3, is used to further test Hypotheses 1a and 1b. SEM is ideally suited to assess causality that occurs between variables in a chain or path. As mentioned above, it is argued that status affects perceptions and perceptions then affect sentencing. Testing this flow of variables with SEM more accurately captures the proposed theoretical model. There are three latent constructs - offender status, perceptions of the offender, and sentencing of the offender - which are comprised of multiple manifest variables the individual questionnaire items.

\section{Figure 3: A Theoretical Model of Status, Perceptions, and Sentencing}

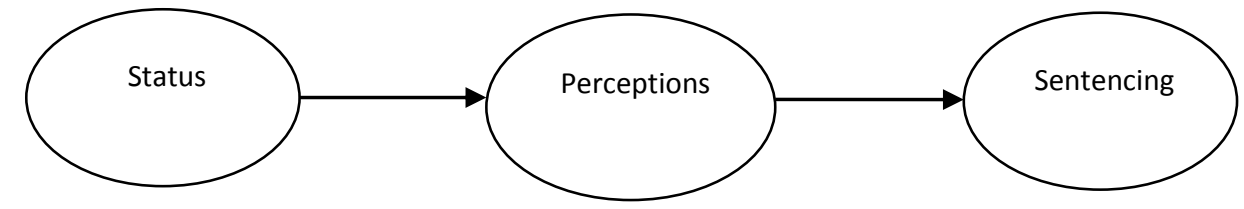

In order to test this model, I employ the two step approach of Anderson and Gerbing (1998). First, exploratory factor analysis (EFA) is used to determine which of the survey items, or manifest variables, most accurately construct the theoretical or latent variable and should be kept in the final measurement scale for that particular latent construct. While EFA gives an initial indication of which measurement variables should be retained and which should be limited, I then employ confirmatory factor analysis (CFA) to further purify the measurement model. Once the correction manifest and latent variables are constructed, a SEM can be performed. 
Recall that offender status is measured via the following variables: status, prestige, honor, morality, competency, and intelligence. Perceptions of the offender is measured by combining the variables of likely to commit the crime in the future, having committed the crime before, likely to commit street crime in the future, likely obeys the law, what the offender did, and blameworthiness. Finally the construct for sentencing is using responses to recommended sentence, minimum sentence agreed upon, and maximum sentence agreed upon. Results of the EFA and CFA confirm that the three measured variables for sentencing factor together to accurately measure the latent construct of sentence. However, many of the measurement items for offender status and perceptions of the offense were removed from the model. The variables morality and intelligence for the construct of offender status were dropped leaving the final construct to include: status, prestige, competency, and honor. Likely to commit street crime in the future and likely obeys the law were dropped from the construct for perceptions of the offender, with the final model including: likely to commit the (same) crime in the future, has committed the (same) crime before, what the offender did was bad/good, and level of offender blameworthiness. The CFA model yields the following fit statistics, which are all within proscribed guidelines (Hatcher 1994): Chi-square $=0.024, \mathrm{RMSEA}=0.062, \mathrm{CFI}=0.959$, $\mathrm{SRMR}=0.074$ and $\mathrm{CD}=0.928$. Figure 5 in Appendix A displays the full measurement model, including the manifest variables measuring each latent construct.

Results of the full structural equation model are presented in Table 6. Although offender status is significantly related to perceptions of the offender, no statistically significant relationship is found between perceptions of the offender and offender sentencing. The results of the SEM continue to support Hypothesis 1a as to the effect of status on perceptions. However, 
there is still no support for Hypothesis $1 \mathrm{~b}$ as to the relationship between perceptions of the offender and sentencing decisions.

Table 6: Structural Equation Model Results Experiment 1

\begin{tabular}{|c|c|c|}
\hline $\begin{array}{c}\text { Independent } \\
\text { Variable }\end{array}$ & Dependent Variables & \\
\hline Offender Status & & Offender Perceptions \\
\hline Offender Perceptions & $\begin{array}{c}.0415 \\
(.1118)\end{array}$ & \\
\hline
\end{tabular}

Notes: Standard Error in parentheses

$* p<.10$ (one-tailed test)

$* * p<.05$ (one-tailed test)

$* * * p<.01$ (one-tailed test)

However, it is possible that other factors which are not included in Experiment 1 may be important when considering what influences sentencing decisions with regard to white-collar criminals. Recall that Experiment 2 considers the role of crime severity and its relationship to status, perceptions and sentencing. The next section reports on results from this experiment.

\section{Experiment 2}

\section{Manipulation Checks}

Experiment 2 tests Hypothesis 2, which states that as crime seriousness increases the impact of status on offender perceptions and sentencing will decrease. In other words, status only benefits the perceptions of a white-collar criminal offender if their crime is not severe. As the personal and societal damages of the crime increase, perceptions of high morality and competency based on status will decrease. A series of manipulation again assess the success of the experimental conditions. $t$-tests in Table 7 show that the high status white-collar criminal receives a higher mean score for all status variables, with all mean differences statistically significant. Thus, the manipulations of status were successful in Experiment 2. 
Table 7: Mean Ratings of Manipulated Status by condition for Experiment 2

\begin{tabular}{|c|c|c|c|}
\hline Variable & $\begin{array}{c}\text { High Status } \\
\mathbf{N}=\mathbf{1 3 2}\end{array}$ & $\begin{array}{c}\text { Low Status } \\
\mathbf{N = 1 3 4}\end{array}$ & $\boldsymbol{t}$ \\
\hline Status & $\begin{array}{c}7.4886 \\
(1.8496)\end{array}$ & $\begin{array}{c}6.4552 \\
(2.1647)\end{array}$ & $-4.1735 * * *$ \\
\hline Prestige & $\begin{array}{c}6.9470 \\
(2.0240)\end{array}$ & $\begin{array}{c}5.3507 \\
(2.2620)\end{array}$ & $-6.0621 * * *$ \\
\hline Honor & $\begin{array}{c}3.5985 \\
(2.2644)\end{array}$ & $\begin{array}{c}2.8209 \\
(2.0587)\end{array}$ & $-2.9312 * *$ \\
\hline Moral & $\begin{array}{c}3.0763 \\
(1.9557)\end{array}$ & $\begin{array}{c}2.5682 \\
(1.8293)\end{array}$ & $-2.1763 * *$ \\
\hline Competent & $\begin{array}{c}6.1908 \\
(2.1913)\end{array}$ & $\begin{array}{c}5.7090 \\
(2.5979)\end{array}$ & $-1.6304 *$ \\
\hline Intelligent & $\begin{array}{c}7.8015 \\
(1.9589)\end{array}$ & $(2.0092)$ & $-3.4302 * * *$ \\
\hline
\end{tabular}

Notes: Standard deviations in parentheses

$* p<.10$ (one-tailed test)

$* * p<.05$ (one-tailed test)

$* * * p<.01$ (one-tailed test)

Table 8 shows the mean rating of the manipulations of crime severity by condition for

Experiment 2. All of the mean scores for levels of severity indicate that subjects correctly

interpreted the $\$ 10,000$ overbilling vignette (low severity) as less severe in its consequences than the $\$ 100,000$ overbilling vignette (high severity). Although only four of the eight variables measuring severity are significant, I still confidently conclude that the manipulations of crime severity in Experiment 2 are also successful.

Table 8: Mean Ratings of Manipulated Severity by condition for Experiment 2

\begin{tabular}{|c|c|c|c|}
\hline Variable & $\begin{array}{c}\text { High Severity } \\
\mathbf{N = 1 3 3}\end{array}$ & $\begin{array}{c}\text { Low Severity } \\
\mathbf{N = 1 3 3}\end{array}$ & $\boldsymbol{t}$ \\
\hline Outraged & $\begin{array}{c}6.9624 \\
(2.2102)\end{array}$ & $\begin{array}{c}6.5191 \\
(2.1710)\end{array}$ & $-1.6439 * *$ \\
\hline Suffered & $\begin{array}{c}7.6692 \\
(1.9058)\end{array}$ & $\begin{array}{c}6.9470 \\
(2.3649)\end{array}$ & $-2.7382 * * *$ \\
\hline \multirow{2}{*}{ Suffered Physically } & $\begin{array}{c}3.4351 \\
(2.5057)\end{array}$ & $\begin{array}{c}2.8485 \\
(2.1311)\end{array}$ & $-2.0457 * *$ \\
\hline \multirow{2}{*}{ Suffered Emotionally } & $\begin{array}{c}6.6466 \\
(2.4439)\end{array}$ & $\begin{array}{c}5.9015 \\
(2.4984)\end{array}$ & $-2.4541 * * *$ \\
\hline \multirow{2}{*}{ Suffered Financially } & $\begin{array}{c}8.8797 \\
(1.6744)\end{array}$ & $\begin{array}{c}8.6061 \\
(1.9291)\end{array}$ & -1.2334 \\
\hline Insulting & 7.5564 & 7.3333 & -.8697 \\
\hline
\end{tabular}




\begin{tabular}{|c|c|c|c|}
\hline & $(1.9283)$ & $(2.2366)$ & \\
\hline \multirow{2}{*}{ Disrespectful } & 8.7143 & 8.4773 & -1.0371 \\
\hline Offensive & $(1.6903)$ & $(2.0170)$ & -.6812 \\
\hline
\end{tabular}

Notes: Standard deviations in parentheses

$* p<.10$ (one-tailed test)

$* * p<.05$ (one-tailed test)

$* * * p<.01$ (one-tailed test)

Experiment 2 used two-way ANOVA's, to examine the differences in offender perceptions and sentencing across conditions (H2). The results of these tests can be seen in Tables 9 and 10, respectively. The only significant finding is in Table 9. Specifically, a significant interaction was found between offender status and crime severity on variable measuring perceptions of what the offender did (good vs. bad) $(F=4.46, p<.05)$. Graph 1 illustrates this interaction. As can be seen in the graph, how respondents view what the offender did does depend on the seriousness of the crime and the status of the offender. The solid blue line represents low status offenders, and shows little difference in mean scores of what the Offender Did relative to the seriousness of the offense. However the dotted red line represents high status offenders, and shows that as the seriousness of the offense increases so to do mean ratings of what the offender did. Specifically, the actions of the high status offender are seen as worse when they commit a crime of high seriousness as compared to a crime with low seriousness. This graph then shows the interaction of status and seriousness of the crime as predicted by Hypothesis 2.

Table 9: $F$-ratios for Series of Two-way ANOVAs on Perceptions of Offender

\begin{tabular}{|c|c|c|c|}
\hline Variable & $\begin{array}{c}\text { Status } \\
\text { (Main Effect) }\end{array}$ & $\begin{array}{c}\text { Severity } \\
\text { (Main Effect) }\end{array}$ & $\begin{array}{c}\text { Status*Severity } \\
\text { (Interaction) }\end{array}$ \\
\hline Likely Future & 1.55 & 0.24 & 0.42 \\
\hline Committed Before & 0.03 & 0.07 & 0.00 \\
\hline Street Crime Future & 2.07 & 3.02 & 0.40 \\
\hline Obeys Law & 0.04 & 0.38 & 1.69 \\
\hline
\end{tabular}




\begin{tabular}{|c|c|c|c|}
\hline Offender Did & 0.02 & 2.19 & $4.46^{* *}$ \\
\hline Blameworthy & 0.30 & 0.17 & 1.52 \\
\hline
\end{tabular}

Notes:

${ }^{*} p<.10$ (two-tailed test)

$* * p<.05$ (two-tailed test)

$* * * p<.01$ (two-tailed test)

Table 10: F-ratios for Series of Two-way ANOVAS on Sentencing

\begin{tabular}{|c|c|c|c|}
\hline Variable & $\begin{array}{c}\text { Status } \\
\text { (Main Effect) }\end{array}$ & $\begin{array}{c}\text { Severity } \\
\text { (Main Effect) }\end{array}$ & $\begin{array}{c}\text { Status*Severity } \\
\text { (Interaction) }\end{array}$ \\
\hline Recommended Sentence & 1.14 & 2.30 & 0.69 \\
\hline Maximum Sentence & 2.02 & 0.73 & 0.56 \\
\hline Minimum Sentence & 0.02 & 3.60 & 1.31 \\
\hline
\end{tabular}

Notes:

${ }^{*} p<.10$ (two-tailed test)

$* * p<.05$ (two-tailed test)

$* * * p<.01$ (two-tailed test)

\section{Graph 1: Interaction Effect of Status and Severity on What Offender Did Variable}

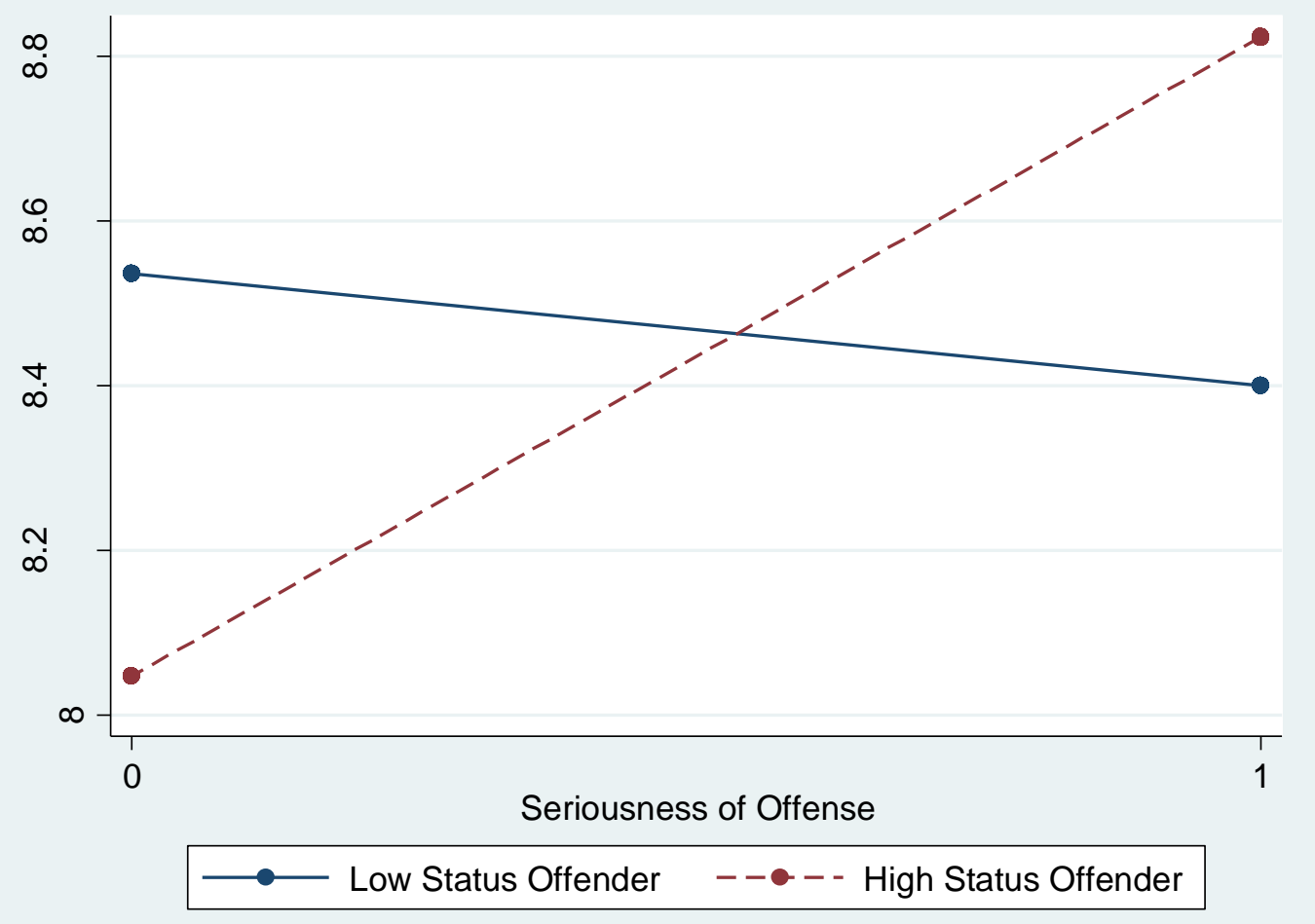

Although two-way ANOVA's only found a statistically significant interaction effect relative to what the offender did, this singular result does align with the prediction in Hypothesis 
2 which asserted that as crime seriousness increases, the impact of status on perceptions and sentencing decreases. However, as in Experiment 1, these basic inferential tests do not fully capture the proposed relationship between status, perceptions, crime severity and sentencing. The following section describes ancillary analyses using structural equation modeling to more fully explore the implications that perceptions and crime severity have for sentencing.

\section{Structural Equation Modeling: Ancillary Test of Hypothesis 2}

The SEM in Figure 4 is used to further test Hypothesis 2 in Experiment 2.

\section{Figure 4: A Theoretical Model of Status, Perceptions, Crime Severity, and Sentencing}

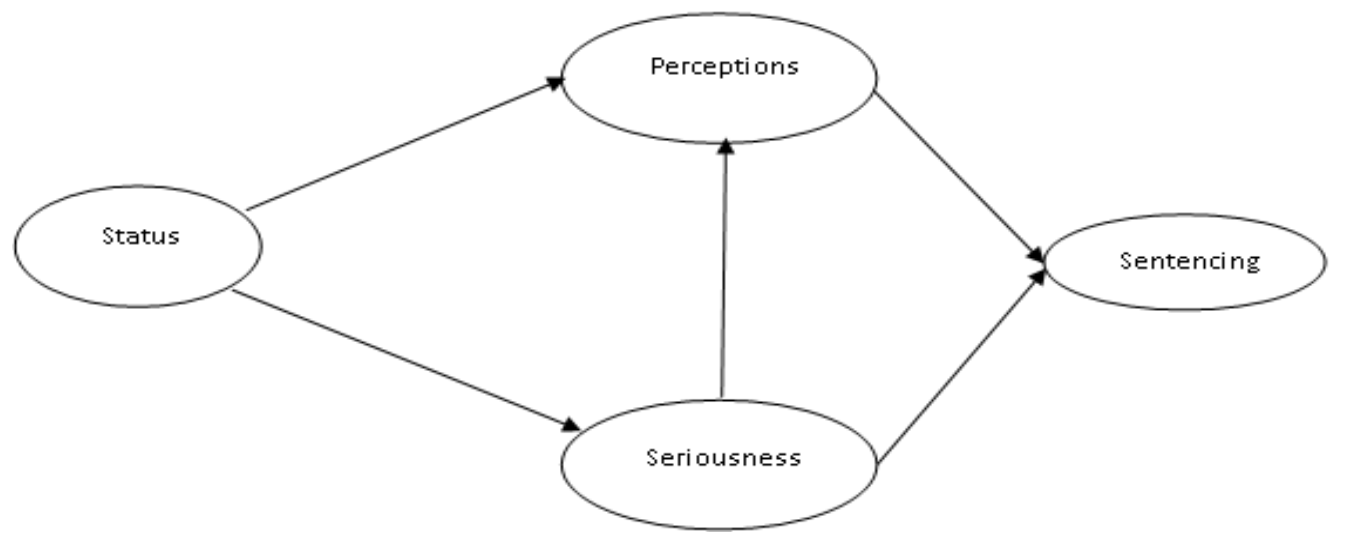

The EFA and CFA two-step approach (Anderson and Gerbing 1998) was again used for

Experiment 2, but the severity of the offense was included as an additional latent construct. The constructs of offense severity, offender's status, perceptions of the offender, and sentencing of the offender were the same as in Experiment 1. Offense severity was initially measured by the variables: outraged, suffered, suffered physically, suffered emotionally, suffered financially, insulting, disrespectful, and offensive. Offense severity for the final SEM was measured via outraged, suffered, suffered emotionally, and suffered financially. The following model fit statistics were obtained for the full measurement model illustrated in Figure 6 in the appendix: Chi-square $=0.000, \mathrm{RMSEA}=0.068, \mathrm{CFI}=0.932, \mathrm{SRMR}=0.075$ and $\mathrm{CD}=0.847$. Again, all values are in line with analytical standards (Hatcher 1994). 
The results of the SEM including offense severity is presented in Table 11. Offender status was found to be significantly related to offense seriousness, offense seriousness was found to be significantly related to offender perceptions, as well as perceptions of the offender and offense severity were found to be significantly related to offender sentencing. Offender's status was found to be related to offense seriousness, such that when the offender's status increases respondents also viewed the offense as more serious. Offender's status then is linked to the seriousness of the crime but not to perceptions of the offender or to sentencing judgments. Offense seriousness was also found to be related to offender sentencing and offender perceptions meaning that as offense seriousness increased so did proposed sentencing or judgments of how harshly an individual should be punished for an offense, as well as perceptions of the offender being a criminal. Offender perceptions were found to be negatively statistically related to offender sentencing, meaning that those who respondents viewed as more criminal were also believed to have been worthy of lighter sentencing. Experiment 1 found that status was related to perceptions, but it did not account for different levels of seriousness for the same crime. Severity was added in Experiment 2 in order to see how the seriousness of the crime impacts judgments of status. Status was not found to matter in sentencing decisions or perceptions of the offender when severity of the crime was also considered. Overall it was found that as crime seriousness increases, the impact of status on perceptions and sentencing decreases. Support then was found for Hypothesis 2, and its assertion that status matters less for perceptions and sentencing decisions when crime seriousness increases.

Table 11: Structural Equation Model Results Experiment 2

\begin{tabular}{|c|c|c|c|}
\hline & \multicolumn{3}{|c|}{ Dependent Variables } \\
\hline $\begin{array}{c}\text { Independent } \\
\text { Variable }\end{array}$ & $\begin{array}{c}\text { Offense } \\
\text { Seriousness }\end{array}$ & $\begin{array}{c}\text { Offender } \\
\text { Perceptions }\end{array}$ & $\begin{array}{c}\text { Offender } \\
\text { Sentencing }\end{array}$ \\
\hline Offender Status & $\begin{array}{c}.1411^{*} \\
(0.722)\end{array}$ & $\begin{array}{c}.0018 \\
(.0622)\end{array}$ & \\
\hline
\end{tabular}




\begin{tabular}{|c|c|c|c|}
\hline Offender & & $\begin{array}{c}-.4280 * * * \\
(.1372)\end{array}$ \\
\hline Perceptions & & & $.4707 * * *$ \\
Offense & & $.7551 * * *$ & $(.1393)$ \\
Seriousness & & $(.0444)$ & \\
\hline
\end{tabular}

Notes: Standard errors in parentheses.

$* p<.10$ (one-tailed test)

$* * p<.05$ (one-tailed test)

$* * * p<.01$ (one-tailed test)

\section{DISCUSSION}

This study used a social psychological theory in order to empirically assess the role of occupation and its effect on perceptions of white-collar criminal offenders and their crimes. The purpose of this research was to evaluate perceptions of the white-collar criminal offender in relation to their occupational status. Employing Status Characteristics Theory allowed for a framework under which these perceptions could be ascertained. Perceptions of white-collar criminal offenders have largely been evaluated by means of comparing white-collar offenders to street criminals. This research was different in that white-collar criminal offenders were compared against each other such that a greater and more comprehensive understanding of perceptions of white-collar criminals could be studied.

The theoretical model used allows for status, perceptions, crime severity, and sentencing to be considered together. I argue that perceptions of white-collar criminal offenders have very much to do with the specific occupational status that the particular white-collar criminal has, and its place within a hierarchically ranked occupational prestige structure. Following the logic of the theoretical model used it is argued that because of the particular status that an individual actor has, there would be certain expectations and assumptions made about that actor. These assumptions are based on beliefs about the actor because of their occupational position. Occupation then acts as a diffuse status characteristic because of its two differential states of 
high versus low prestige. Those in the high status occupation are assumed and expected to act more morally, be more trustworthy, and overall be more competent as compared to those in the low status group (Parsons, 1954; Shils, 1968; Treiman, 1977; Veblin, 1919).

Experiment 1 examined the relationship between the occupational status of a white-collar criminal and perceptions of that criminal's morality, blameworthiness and honor. This experiment also investigated the implications of occupational status and perceptions on sentencing. It was hypothesized that (H1a) criminals from more prestigious occupational positions because of their high status would be considered less criminal and that (H1b) because of their high status, criminals from more prestigious occupations would be punished less harshly. Hypothesis 1a was supported: Occupational status does have an effect on perceptions of white-collar criminal offenders, with those occupying lower status positions seen as more criminal compared to high status individuals who commit the same crime. When severity of crimes committed was equal and the only difference in the crimes was the occupational status of the individual, implications were also found for sentencing decisions. However, Hypothesis $1 \mathrm{~b}$ was not supported. It was predicted because of status considerations that high status individuals would be punished less harshly, but it was actually found that subjects believed that high status individuals should be punished more harshly.

Initial analysis using $t$-tests did not fully capture the proposed causal relationship between status, perceptions, and sentencing. Using structural equation modeling allowed for an examination of the path-nature of the relationship between variables rather than an assessment of a direct link between offender status and offense sentencing. SEM showed that offender's status affects perceptions and perceptions then in turn affect sentencing. For the study of white-collar 
crime this means that occupational status does exist and is something to consider when studying perceptions of white-collar criminal offenders.

Based on the findings in Experiment 1, this research has theoretical implications for Status Characteristics Theory. SCT holds that assumptions are made about individuals because of a certain status that they have, specifically in this study the status of occupation. Based on manipulation checks and testing of the relationship between variables it can be concluded, as SCT asserts, that occupation acts as a diffuse status characteristic. As a diffuse status characteristic there are recognized differentiated levels of occupation. SCT also holds that because of this recognized status, those who are in the presumed advantageous or high status state of a characteristic will act more morally, in a more trustworthy way, and more competently compared to those in a lower occupational position. However, when white-collar criminal offenses are used to study occupation as a diffuse status characteristic then, status considerations are inherently violated. It is expected that those in the higher prestige occupational position will act morally, in a trustworthy manner, and competently, but committing a white-collar crime violates all these expectations and assumptions. It may be for this very reason then that the findings on sentencing decisions were in the opposite direction of what was predicted. Status considerations may have become particularly salient in the consideration of a white-collar crime because of how white-collar crime violates our expectations of high status individuals, and the strong implications that these status violations bring with them. Rather than status acting to protect the high status individuals and having a mediating effect on sentencing decisions as SCT holds and was proposed, it may have the opposite effect. High status people may not be viewed then as worse or more of a criminal than lower status individuals. However, because of their status and their violation of our trust and the assumptions that we make of them, people may be 
more offended or hurt, and in favor of harsher punishment when status expectations are violated by high status persons. SCT doesn't predict such a backlash when people violate status expectations but other work finds that this happens. For example neighborhood research on policing finds that residents experience a similar violation of expectations when crime occurs (Nolan, Conti, and McDevitt 2004). Residents expect police officers to be effective in reducing crime and when they are not and these expectations they hold are violated, it becomes more salient and troublesome to people (Nolan et al. 2004). Just as groups form expectations as held by SCT, when they are based on a diffuse status characteristic, the role of a police officer brings with it expectations of the neighborhood as a whole. When these status violations occur because of the unrealistic perception that police alone prevent crime, just as the status violation that high status occupational individuals will not commit white-collar crime, the reaction to this status violation is similar. Frustration and conflict develop in the neighborhoods because of this violation of expectations, just as in status violations concerning white-collar offenders and the reaction of others to their crimes in relation to their unrealistic perceptions of them based on their occupation.

Experiment 2 added considerations of crime severity to the relationship between status, perceptions and sentencing among white-collar criminals. The goal of this experiment then, was to see if as crime seriousness increased whether the impact of status on perceptions and sentencing would decrease $(\mathrm{H} 2)$. Status was found to interact with crime severity; while crime severity was found to interact with perceptions of the offender and sentencing. Specifically, as offender status increases so too do considerations of crime seriousness. Status then has diminishing affects when crime severity is also considered, even when status violations occur. A different type of status violation occurs in experiment 2 because of the consideration of 
comparative seriousness of the offense. In experiment 2 someone who is of high occupational status should not be committing a criminal offense that is comparatively worse because of the assumptions that we make about their status. Status should matter when expectations of a certain status are violated, but as found in Experiment 2 it only matters so much, and though status violations can be alarming and result in harsher judgments because of status, these status considerations become less relevant when crime severity is also considered.

While status was not found to directly impact sentencing decisions, it was found to relate to offense seriousness which in turn affects perceptions and sentencing decisions. Furthermore, offender sentencing was related to perceptions of the offender and severity of the crime in Experiment 2. Findings on crime seriousness and how it relates to the impact of status on perceptions and sentencing mean that although status considerations do exist, when the severity of a crime is also considered and made apparent, the status of a white-collar criminal has less meaning in its implications on perceptions and sentencing. The results from Experiment 2, when taken together with the results of Experiment 1 reasonably conclude that occupation does play a role in perceptions of white-collar criminal offenders, but that its role and impact can be somewhat diminished when other elements of the crime are factored in.

Status Characteristics Theory was useful in studying white-collar crime and the role of occupation in perceptions of white-collar criminals and white-collar criminal offenses. SCT allowed for the specific comparison of high and low levels of occupational status and provided for a new way to study perceptions. Committing a white-collar crime is also committing a status violation. In order to further test SCT and its assumptions the idea of status violations and the implications that they have for status and its diminishing effect in certain situations must be further explored. 
The current study was limited in that the sample used was one of convenience and that only a small amount of white-collar crimes were tested compared to the large expanse of whitecollar crimes that exist. While the sample could be improved and some may question its generalizability, research has found that student samples are both representative and reliable overall compared to sampling other populations (Sellin and Wolfgang 1964; Akman and Normandeau 1967). The examination of other types of white-collar crimes could result in a greater or lesser recognized status effect. For instance, crimes that have further reaching implications and affect a larger amount of people, as well as crimes that are committed by government agencies may elicit different responses and hold different status considerations and assumptions relative to occupation. A further limitation that was not considered until after the study was complete was the use of names in vignettes. The vignettes used two different names, one for the higher occupational status individual and one for the lower occupational status individual. Although I believe no inferences could be made based on names of the offenders that may affect perceptions, it is a limitation worth noting. In order to see if occupational status does exist and if its diminishing effects relative to crime seriousness are consistent across occupations and type of crime, further research must be done specifically looking at the interaction of status and crime seriousness. Future research could also further investigate the role of status by including more types of white-collar criminals, testing other occupational positions, and testing a much broader audience.

Crime and its impact on society will forever be of interest to sociologists. Crime has far reaching implications and will continue to evolve over time. Americans continue to build more prisons and imprison more people than any other country in the world. Studying crime and perceptions of criminals will become ever more important as determinations of what sentences 
are applied to different types of criminals, and which criminals are important enough to prosecute become poignant issues. White-collar crime and white-collar criminals may deserve more focus of future efforts to study crime because of the increase of white-collar crime and corresponding decrease in other types of criminality. As white-collar crime becomes increasingly differentiated, entered into by many capable actors, and incredibly damaging, its far reaching implications become ever more important in an increasingly globalized world. While whitecollar crime has been historically viewed as a crime of the business elite, it is quickly becoming a more commonplace form of criminality. Understanding perceptions of differentiated levels of occupation and the role of status in perceptions of white-collar criminals then, proves to be important in a real world sense because of how perceptions affect sentencing decisions.

While this research aimed at a greater understanding of white-collar crime and the specific role of occupation in perceptions of white-collar criminals, it like other studies on whitecollar crime does not even begin to scratch the surface on fully understanding perceptions of white-collar criminals. It can be said that occupation and seriousness of the offense matter, but there are many other factors to consider as well. This research then is just one small piece of the very large puzzle that is studying white-collar crime and perceptions of white-collar criminals. 


\section{References:}

Agnew, Robert., Nichole Leeper Piquero, and Francis T. Cullen. 2009. "General Strain Theory and White-Collar Crime.” The Criminology of White-Collar Crime 1:35-60.

Akman, Dogan D. and Andre Normandeau. 1967. "The Measurement of Crime and Delinquency in Canada." British Journal of Criminology 7(2):129-149.

Almond, Paul. 2009. "Understanding the seriousness of corporate crime: Some lessons for the new ‘corporate manslaughter' offence.” Criminology and Criminal Justice 9:145-164.

Anderson, James C. and David W. Gerbing. 1988. "Structural Equation Modeling in Practice: A Review and Recommended Two-Step Approach.” Psychological Bulletin 103:411-

423.Benediktsson, Mike Owen. 2010. "The Deviant Organization and the Bad Apple CEO: Ideology and Accountability in Media Coverage of Corporate Scandals." Social Forces 88:2189-2216.

Berman, Mitchell. 2007-2008. "On the Moral Structure of White Collar Crime.” Ohio State Journal of Criminal Law 54:301-327.

Benson, Michael L. and Elizabeth Moore. 1992. "Are White-Collar and Common Offenders the Same? An Empirical and Theoretical Critique of a Recently Proposed General Theory of Crime." Journal of Research in Crime and Delinquency 29:251-272.

Benson, Michael., Tamara D. Madensen, and John E. Eck. 2009. "White-Collar Crime from an Opportunity Perspective.” The Criminology of White-Collar Crime 3:175-193.

Benson, Muchael. and Esteban Walker. 1988. "Sentencing the White-Collar Offender." American Sociological Review 53(2):294-302. 
Beresford, Annette D., Christian Desliets, Sandra Haantz, John Kane, and April Wall. 2005. "Intellectual Property and White-Collar Crime: Report of Issues, Trends, and Problems for Future Research." Trends in Organized Crime 8:62-78.

Berger, Joseph., Bernard P. Cohen, and Morris Zelditch, Jr. 1972. "Status Characteristics and Social Interaction.” American Sociological Review 37:241-255.

Berger, Joseph. And Murray Webster. 2006. “Expectations, Status, and Behavior.” Pp. 268-300 in Contemporary Social Psychology, edited by Peter J. Burke. Stanford, CA: Stanford Social Sciences.

Berger, Joseph., Susan J. Rosenholtz and Morris Zelditch Jr. 1980. “Status Organizing Processes.” Annual Review of Sociology 6:479-508.

Berman, Mitchell N. 2007. “On The Moral Structure of White Collar Crime.” Ohio State Journal of Criminal Law 5:301-327.

Brand, V. 2008. "Empirical Business Ethics Research and Paradigm Analysis.” Journal of Business Ethics 86:429-449.

Brody, Richard G. and Kent A. Kiehl. 2010. "From white-collar crime to red-collar crime." Journal of Financial Crime 17:351-364.

Burke, Peter J. 2006. Contemporary Social Psychological Theories. Stanford, CA. Stanford Social Sciences.

Burton, Hughlene., Stewart Karlinsky, and Cindy Blanthorne. 2005. "Perception of a WhiteCollar Crime: Tax Evasion.” American Taxation Association Journal of Legal Tax Research 1-22. 
Cavender, Gray. and Aogan Mulcahy. 1998. "Trial By Fire: Media Constructions of Corporate Deviance.” Justice Quarterly 15:697-717.

Cherry, John., Monle Lee, and Charles S. Chien. 2003. “A Cross-Cultural Application of a Theoretical Model of Business Ethics: Bridging the Gap between Theory and Data." Journal of Business Ethics 44(4):359-376.

Chirayath, Verghese., Kenneth Eslinger, and Ernest De Zolt. 2002. "Differential Association, Multiple Normative Standards, and the Increasing Incidence of Corporate Deviance in an Era of Globalization.” Journal of Business Ethics 41(1/2):131-140.

CBS News Poll (2002, July 8-9). from http://www.PollingReport.com.

Cohan, John Alan. 2002. “'I Didn’t Know' and 'I was Only Doing My Job’: Has Corporate Governance Careened Out of Control? A Case Study of Enron's Information Myopia." Journal of Business Ethics 40:275-299.

Cohen, Elizabeth G. and Susan S. Roper. 1972. "Modification of Interracial Interaction Disability: An Application of Status Characteristic Theory." American Sociological Review 37:643-657.

Cohen, Mark A. 1988. “Some New Evidence On The Seriousness Of Crime.” Criminology 26:343-353.

Coleman, James Williams. 1987. "Toward and Integrated Theory of White-Collar Crime." The American Journal of Sociology 93(2):406-439. 
Cornelius, Nelarine., James Wallace, and Rana Tassabehji. 2007. “An analysis of Corporate Social Responsibility, Corporate Identity and Ethics Teaching in Business Schools.” Journal of Business Ethics 76:117-135.

Croall, Hazel. 1989. "Who Is The White-Collar Criminal?" British Journal of Criminology 29(2):157-174.

Cullen, Francis T., Bonnie S. Fisher, and Brandon K. Applegate. 2000. "Public Opinion about Punishment and Corrections.” The University of Chicago Press 27:1-79.

Cullen, Francis T., Jennifer L. Hartman, and Cheryl Lero Jonson. 2009. "Bad guys: Why the public supports punishing white-collar offenders." Crime Law and Social Change 51:3144.

Cullen, Francis T., Bruce G. Link, and Craig W. Polanzi. 1982. "The Seriousness of Crime Revisited Have Attitudes Toward White-Collar Crime Changed?" Criminology 20:83102.

Dhami, Mandeep K. 2006. “White-collar prisoners' perception of audience reaction.” Deviant Behavior 28:57-77.

Lisa M. Dilks, Tucker McGrimmon, and Shane R. Thye. 2011. "Status, Emotions, and the Origins of Sentencing Disparities."

Douhou, Salima., Jan R. Magnus, and Arthur van Soset. 2011. "The perception of small crime." European Journal of Political Economy 27:749-763. 
Ermann, David M. and Richard J. Lundman. 2002. Corporate and Governmental Deviance: Problems of Organizational Behavior in Contemporary Society New York, NY: Oxford University Press.

Evans, Sandra S. and Joseph E. Scott. 1984. "Effects of Item Order on the Perceived Seriousness of Crime: A Reexamination.” Journal of Research in Crime and Delinquency 21:139151.

Evans, Sandra S. and Joseph E. Scott. 1984. "The Seriousness of Crime Cross-Culturally." Criminology 22(1):39-59.

Gallup Poll. (1988, December). Honesty and ethical standards (Report No. 279, pp. 1-40). Princeton, NJ: Author.

Glenn, Norval D. 1975. "The Contribution of White Collars to Occupational Prestige." The Sociological Quarterly 16:184-189.

Goldstein, Abraham. 1982. "Defining the Role of the Victim in Criminal Prosecution." Mississippi Law Journal 52:515-560.

Gordon, Randall A., Thomas A. Bindrim, Michael L. McNichols, and Teresa L. Walden. 1988. "Perceptions of Blue-Collar and White-Collar Crime: The Effect of Defendant Race on Simulated Juror Decisions." The Journal of Social Psychology 128:191-197.

Greenberg, Jerald. 2002. "Who stole the money, and when? Individual and situational determinants of employee theft." Organizational Behavior and Human Decision Processes 89:985-1003. 
Hagan, John., Irene H. Nagel, and Celesta Albonetti. 1980. "The Differential Sentencing of White-Collar Offenders in Ten Federal District Courts.” American Sociological Review 45(5):802-820.

Hamilton, V. Lee., and Joseph Sanders. 1996. “Corporate Crime through Citizens” Eyes: Stratification and Responsibility in the United States, Russia, and Japan." Law and Society Review 30(3):513-548.

Hans, Valerie P. and M. David Ermann. 1989. "Responses to Corporate versus Individual Wrongdoing." Law and Human Behavior 13:151-166.

Hatcher, Larry. 1994. A Step-by-Step Approach to Using SAS for Factor Analysis and Structural Equation Modeling. SAS Institute Inc.: Cary, NC.

Hazel, Coral. 1989. "Who is the White-Collar Criminal." British Journal of Criminology 29(2):157-174.

Herz, Annette., and Harald Kania. 2002. "Everyday Perceptions of Crime.” European Journal of Crime, Criminal Law and Criminal Justice 10:276-285.

Herzog, Sergio. 2008. "An Attitudinal Explanation of Biases in the Criminal Justice System: An Empirical Testing of Defensive Attribution Theory." Crime and Delinquency 54(3):457481.

Herzog, Serigo. 2003. "Does the Ethnicity of Offenders in Crime Scenarios Affect Public Perceptions of Crime Seriousness? A Randomized Survey Experiment in Israel.” Social Forces 82:757-781. 
Herzog, Sergio. 2003. "Religiosity and perceptions of crime seriousness by Jewish and Muslim respondents in Israel." Deviant Behavior, An Interdisciplinary Journal 24:153-174.

Herzog, Serigo. and Shaul Oreg. 2008. "Chivalry and the Moderating Effect of Ambivalent Sexism: Individual Differences in Crime Seriousness Judgments." Law and Society Review 42:45-74.

Heumann, Milton, Brain Pinaire, and Thomas Clark. 2005. Beyond the sentence: Public perceptions of collateral consequences for felony offenders. Criminal Law Bullentin 41:24-46.

Hodge, Robert., Paul M. Siegel, and Robert H. Rossi. 1964. "Occupational Prestige in the United States, 1925-63." American Journal of Sociology 70:286-302.

Holtfreter, Kirsty., Nicole Leeper Piquero., and Alex R. Piquero. 2008. “And justice for all? Investigators' perception of punishment for fraud perpetrators." Crime Law and Social Change 49:397-412.

Holtfreter, Kirsty., Shanna van Slyke, Jason Bratton, and Marc Gertz. 2008. "Public perceptions of white-collar crime and punishment." Journal of Criminal Justice 36:50-60.

Isenring, Giang Ly. 2008. "Perception of Seriousness and Concern about White-Collar Crime: Some Results of and Opinion Survey Among Swiss Banks." European Journal Criminal Policy Research 14:371-389.

Jones, Gwen E. and Michael J. Kavanagh. 1996. “An Experimental examination of the Effects of Individual and Situational Factors on Unethical Behaviors Intentions in the Workplace.” Journal of Business Ethics 15(5):511-523. 
Kerley, Kent R. and Hieth Copes. 2004. "The Effects of Criminal Justice Contact on Employment Stability for White-Collar and Street -Level Offenders.” International Journal of Offender Therapy and Comparative Criminology 48:65-84.

Kohn, Melvin., and Carmi Schooler. 1969. "Class, Occupation, and Orientation.” American Sociological Review 34:659-678.

Kraus, Vered., E.O. Schild, and Robert W. Hodge. 1978. "Occupational Prestige in the Collective Conscience." Social Forces 56:900-918.

Kwan, Ying Keung., Lai Lin Chiu, Wai Cheong Ip, and Patrick Kwan. 2002. "Perceived crime seriousness Consensus and disparity." Journal of Criminal Justice 30:623-632.

Langton, Lynn. and Nicole Leeper Piquero. 2007. "Can general strain theory explain white-collar crime? A preliminary investigation of the relationship between strain and select whitecollar offenses." Journal of Criminal Justice 35:1-15.

Levi, Michael. 2009. "White-Collar Crimes and the Fear of Crime: A Review." The Criminology of White-Collar Crime Part II:79-109.

Levi, Michael. 2008. "White-collar, organized and cyber crimes in the media: some contrasts and similarities." Crime Law and Social Change 49:365-377.

Los Angeles Times Poll (2004, March 27-30). from http://www.PollingReport.com.

40. Los Angeles Times/Bloomberg Poll (2007, June 7-10). from http://www.PollingReport.com. 
Marsh, Robert M. 1971. "The Explanation of Occupational Prestige Hierarchies." Social Forces $50: 214-222$.

McCreath, Alistair., 2001. "Sentencing and the perception of risk." The Journal of Forensic Psychiatry 12(3):459-499.

Meithe, Terrance. 1982. "Public Consensus on Crime Seriousness: Normative Structure or Methodological Artifact?” Criminology 20(3):515-526.

Mueller-Johnson, Katrin U. and Mandeep K. Dhami. 2010. "Effects of Offenders' Age and Health on Sentencing Decisions.” The Journal of Social Psychology 150(1):77-97.

Murray, Webster. and James E. Driskell. 1983. "Beauty as Status.” American Journal of Sociology 89:140-165.

Nakao, Keiko., and Judith Treas. 1994. "Updating Occupational Prestige and Socioeconomic Scores: How the New Measures Measure up.” Sociological Methodology 24:1-72.

Naso, Ronald C. 2011.”When Money and Morality Collide White-Collar Crime and the Paradox of Integrity." Psychoanalytic Psychology 29:412-254.

National White Collar Crime Center (1999, 2000, 2005, 2010). National Public Survey on White Collar Crime. Fairmont, WV: National White Collar Crime Center.

Newman, Graeme R. and Carol Trilling. 1975. "Public Perceptions of Criminal Behavior: A Review of the Literature." Criminal Justice and Behavior 2:217-234.

Nobling, T., Spohn, C., \& DeLone M. 1998. "A tale of two counties: Unemployment and sentence severity.” Justice Quarterly 15(3):459-485. 
Nolan, James., Norman Conti, and Jack McDevitt. 2004. "Situational Policing: Neighbourhood Development and Crime Control.” Policing \& Society 14(2): 99-117.

O’ Connell, Michael. and Anthony Whelan. 1996. “Taking Wrongs Seriously: Public Perceptions of Crime Seriousness." British Journal of Criminonlgy 36(2):299-318.

O'Connor, Michael E. 1984. The perception of crime and criminality: The violent criminal and swindler as social types. Deviant Behavior 5:255-274.

Piquero, Nicole Leeper., M. Lyn Exum, and Sally S. Simpson. 2005. "Integrating the Desire-forControl and rational Choice in a Corporate Crime Context." Justice Quarterly 22(2):252278.

Piquero, Nicole., Stephanie Carmichael, and Alex R. Piquero. 2008. “Assessing the Perceived Seriousness of White-Collar and Street Crimes." Crime and Delinquency 54:291-312.

Piquero, Nicole Leeper. and Andrea Schoepfer. 2010. "Theories of White-Collar Crime and Public Policy." Criminology and Public Policy: Putting Theory to Work 188-200.

Piquero, Nicole Leeper., Stephen G. Tibbetts, and Michael B.Blankenship. 2005. "Examining the role of differential association and techniques of neutralization in explaining corporate crime." Deviant Behavior 26:159-188.

Podogor, Ellen S. 2007. “The Challenge of White Collar Sentencing.” The Journal of Criminal Law and Criminology 97:731-758.

Podgor, Ellen. 2011. "100 Years of White Collar Crime in 'Twitter'.” The Review of Litigation 30:535-558. 
Pontell, Henry. and Gilbert Geis. 2007. "Black Mist and White Collars: Economic Crime in the United States and Japan.” Asian Journal of Criminology 2:111-126.

President's Commission on Law Enforcement and Administration of Justice (1968). Challenge of crime in a free society. New York: Avon.

Rebovich, Donald J., and John Kane. 2002. "An Eye for and Eye in the Electronic Age: Gauging Public Attitude Toward White Collar Crime and Punishment." Journal of Economic Crime Management 1:1-19.

Roberts, Julian V. 1992. "Public Opinion, Crime, and Criminal Justice" Crime and Justice 60:99-180

Robinson, Dawn T., Lynn Smith-Lovin and Olga Tsoudis. 1994. "Heinous Crime or Unfortunate Accident? The Effects of Remorse on Responses to Mock Criminal Confessions.” Social Forces 73:175-190.

Rosenmerkel, Sean P. 2001.”Wrongfulness and Harmfulness as Components of Seriousness of White-Collar Offenses." Journal of Contemporary Criminal Justice 17(4):308-327.

Ross, Edward Alsworth. 1907. "The Criminaloid: An Early Sociologist Examines Deviance by Powerful People and Their Organizations.” The Atlantic Monthly 99:44-50.

Rossi, Peter H., Emily Waite, Christine E. Bose, and Richard E. Berk. 1974. "The Seriousness of Crimes: Normative Structure and Individual Differences.” American Sociological Review 39:224-237.

Rossi, Peter H., Jon E. Simpson, and JoAnn L. Miller. 1985. “Beyond Crime Seriousness: Fitting the Punishment to the Crime." Journal of Quantitative Criminology 1:59-90. 
Schoepfer, Andrea., Stephanie Carmichael, and Alex R. Piquero. 2007. "Do Perceptions of punishment vary between white-collar and street crimes?" Journal of Criminal Justice 35:151-163.

Severson, Kim. 2011. “A Revered Educator’s Fall From Grace.” The New York Times.

Shichor, David. 2009. "'Scholarly Influence' and white-collar crime scholarship." Crime Law and Social Change 51:175-187.

Shoepfer, Andrea., and Nicole Leeper Piquero. 2006. "Exploring white-collar crime and the American dream: A partial test of institutional anomie theory." Journal of Criminal Justice 43:227-235.

Simpson, Sally S. and David Weisburd. 2009. "Introduction.” Pp. 3-13 in The Criminology of White-Collar Crime edited by S.S. Simpson and David Weisburd. New York, NY: Springer New York

Sims,Randil., A Ercan Gegez. 2004. "Attitudes Towards Business Ethics: A Five Nation Comparative Study." Journal of Business Ethics 50(3):253-265.

Sims, Ronald R., Johannes Brinkmann. 2003. “Enron Ethics (Or: Culture Matters More than Codes)." Journal of Business Ethics 45:243-256.

Simmons, Roberta G. and Morris Rosenberg. 1971. "Functions of Children's Perceptions of the Stratification System.” American Sociological Review 36:235-249.

Strader, Kelly J. 2007. "White Collar Crime and Punishment: Reflections on Michael, Martha, and Milberg Weiss." Mason Law Review 15:45-62. 
Stylianou, Stelios. 2003. "Measuring crime seriousness perceptions: What have we learned and what else do we want to know." Journal of Criminal Justice 31:37-56.

Time (1969, June 6). Changing morality: The two Americas-A Time-Louis Harris Poll, pp. 26 27.

Time (2002, June 17). Corporate greed: Heroes to heels, p. 48.

Time/CNN Poll (2002, July 22). Losing faith in corporate America, pp. 18-19.

Treiman, Donald J. 1977. Occupational Prestige in Comparitive Perspective. New York, NY: Academic Press, INC.

Tsalikis, John., Bruce Seaton. 2007. “The International Business Ethics Index: European Union.” Journal of Business Ethics 75(3):229-238.

Tsoudis, Olga. 2000. "Relation of Affect Control Theory to the Sentencing of Criminals.” The Journal of Social Psychology. 140:473-485.

Tsoudis, Olga and Lynn Smith-Lovin. 1998. "How Bad Was It? The Effects of Victim and Perpetrator Emotion on Responses to Criminal Court Vignettes.” Social Forces 77:695-722.

United States Department of Justice. 2005. United States Department of Justice: Fiscal year 2005 budget and performance summary.

Van Slyke, Shanna, "Social Identification and Public Opinion on White-Collar Crime" (2009). Electronic Theses, Treatises and Dissertations. Paper 4563.

Walker, Monica A. 1978. Measuring the seriousness of crimes. British Journal of Criminology 18:348-364. 
Warr, Mark. 1989. “What is the Perceived Seriousness of Crimes?” Criminology 27:795821.Webster, Murray Jr., Stuart J. Hysom, and Elise M. Fullmer. 1998. "Sexual Orientation and Occupation as Status.” Advances in Group Processes 15:1-21.

Weisburd, David., Ellin Waring, and Stanton Wheeler. 1990. "Class, Status, and the Punishment on White-Collar Criminals.” Law and Social Inquiry 15:223-243.

Wheeler, Stanton., David Weisburd, Ellin Waring, and Nancy Bode. 1987-1988. "White Collar Crimes and Criminals.” American Criminal Law Review 25:331-357.

Wheeler, Stanton., David Weisburd, and Nancy Bode. 1982. "Sentencing the White-Collar Offender: Rhetoric and Reality." American Sociological Review 47:641-659.

Yeager, Peter Cleary. 2008. "Science, values and politics: an insider's reflections on corporate crime research." Crime Law and Social Change 51:5-30. 


\section{APPEDNICIES}

\section{Appendix A}

Figure 5: Final Measurement Model

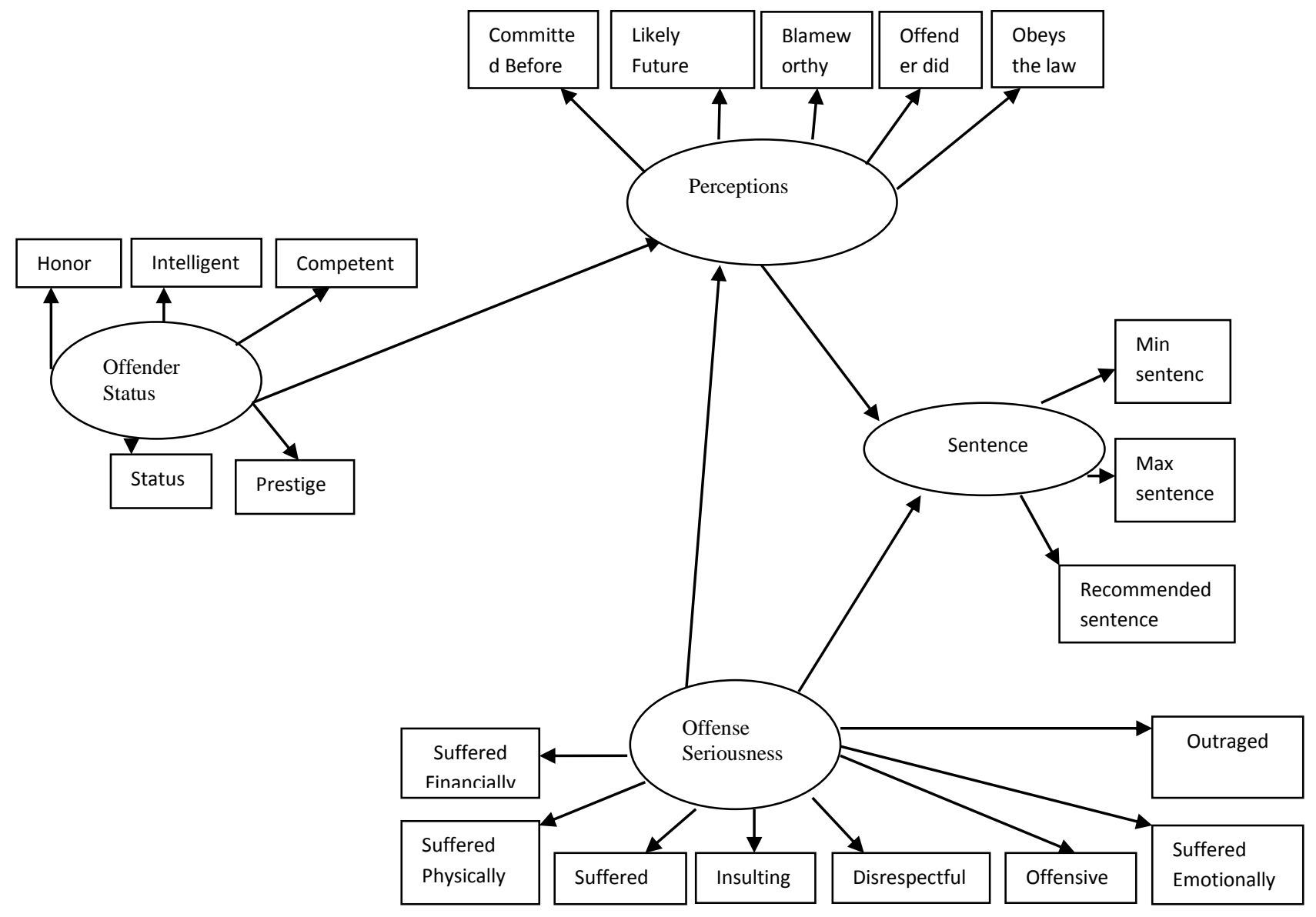




\section{Appendix B}

Title of Study: Perceptions of White Collar Criminals and Their Crimes

\section{Principal Investigators:}

Dr. Lisa Dilks

Assistant Professor of Sociology

WVU Department of Sociology and Anthropology

(304) 293-0455

Marshall Schmidt

Graduate Student

WVU Department of Sociology and Anthropology

(304) 293-8845

\section{Background:}

You are being invited to take part in a research study. Before you decide to participate in this study, it is important that you understand why the research is being done and what it will involve. Please take the time to read the following information carefully. Please ask the researcher if there is anything that is not clear or if you need more information.

The purpose of this study is to examine people's perceptions of white-collar criminals and their crimes.

\section{Risks:}

The risks of this study are minimal. You may decline to answer any or all questions and you may terminate your involvement at any time if you choose.

\section{Benefits:}

There will be no direct benefit to you for your participation in this study. However, we hope that the information obtained from this study may help to further the field of sociology.

\section{Confidentiality:}

Please do not write any identifying information on your questionnaire. Your responses will be anonymous and confidential.

\section{Voluntary Participation:}

Your participation in this study is voluntary. It is up to you to decide whether or not to take part in this study. If you do decide to take part in this study, you will be asked to sign a consent form, and you are still free to withdraw at any time and without giving a reason. You are free to not answer any question or questions if you choose. This will not affect the relationship you have 
with the researcher. If you do not want to be in the study, you may choose not to participate and leave your answers blank, or you may read quietly at your desk. There will be no cost or monetary compensation for participation.

\section{Unforeseeable Risks:}

There may be risks that are not anticipated. However every effort will be made to minimize any risks.

\section{Person To Contact:}

Should you have any questions about the research or any related matters, please contact either of the principal investigators at $\underline{\text { mschmid7@ mix.wvu.edu }}$ or lisa.dilks@ mail.wvu.edu

\section{Institutional Review Board:}

If you have questions regarding your rights as a research subject, or if problems arise which you do not feel you can discuss with the investigator, please contact the Institutional Review Board Office at (304) 293- 7073.

\section{Consent:}

By completing this survey, I confirm that I have read and understood the information and have had the opportunity to ask questions. I understand that my participation is voluntary and that I am free to withdraw at any time, without giving a reason and without cost. I understand that I will be given a copy of this consent form. I voluntarily agree to take part in this study. 


\section{$\underline{\text { Instructions: }}$}

After consenting to participate in our study, we ask that you carefully read the following scenario and take about 5 minutes to answer some questions about it. You will be asked to read about an occurrence of a white-collar or occupational crime, which will include a short description of the crime and the criminal. You will then be asked questions about your perceptions of the crime and the criminal. Please complete the study in the order in which it has been given to you, starting with the first page and continuing to the last. Please give your honest opinion and feelings when answering questions. Your participation in this study is strictly voluntary and will not, in any way, affect your grade for this course. If you choose to participate, all responses will remain confidential and anonymous. If you have questions about this study you can contact Dr. Lisa Dilks at (304) 293-0455 or lisa.dilks@ mail.wvu.edu.

Robert Sullivan is a lawyer who works for a large law firm in a major city. Robert overbills his clients for hours during which he did not work on their case. As a result, Robert's firm earns an extra $\$ 10,000$ a year.

Please take a moment and THINK ABOUT THE OFFENDER in this instance of white-collar crime. Answer each of the following questions by choosing the number that corresponds to your judgment about the OFFENDER. Remember, there are no right or wrong answers.

1. How likely is it that the offender will commit this crime in the future?

Not Likely

$\begin{array}{llllllllll}1 & 2 & 3 & 4 & 5 & 6 & 7 & 8 & 9 & 10\end{array}$

2. How often do you think the offender has committed this crime before?

Not Often

Very Often

$\begin{array}{llllllllll}1 & 2 & 3 & 4 & 5 & 6 & 7 & 8 & 9 & 10\end{array}$

3. How likely is it that the offender will commit a street crime (e.g. robbery, burglary, grand theft auto) in the future? 
Not Likely

Very Likely

$\begin{array}{llllllllll}1 & 2 & 3 & 4 & 5 & 6 & 7 & 8 & 9 & 10\end{array}$

4. In your opinion how likely is it that the offender generally obeys the law?

Not Likely

Very Likely

$\begin{array}{llllllllll}1 & 2 & 3 & 4 & 5 & 6 & 7 & 8 & 9 & 10\end{array}$

5. In your opinion, how much status does the offender generally possess?

Low status

High Status

$\begin{array}{llllllllll}1 & 2 & 3 & 4 & 5 & 6 & 7 & 8 & 9 & 10\end{array}$

6. In your opinion, how much prestige does the offender generally possess?

Low prestige

High prestige

$\begin{array}{llllllllll}1 & 2 & 3 & 4 & 5 & 6 & 7 & 8 & 9 & 10\end{array}$

7. In your opinion, how generally honorable is the offender?

Not honorable

Honorable

$\begin{array}{llllllllll}1 & 2 & 3 & 4 & 5 & 6 & 7 & 8 & 9 & 10\end{array}$

8. In your opinion, how generally moral is the offender?

Not honorable

High Status

$\begin{array}{llllllllll}1 & 2 & 3 & 4 & 5 & 6 & 7 & 8 & 9 & 10\end{array}$


9. In your opinion, how generally competent is the offender?

Not competent

Very competent

$\begin{array}{llllllllll}1 & 2 & 3 & 4 & 5 & 6 & 7 & 8 & 9 & 10\end{array}$

10. In your opinion, how generally intelligent is the offender?

Not intelligent

Very Intelligent

$\begin{array}{llllllllll}1 & 2 & 3 & 4 & 5 & 6 & 7 & 8 & 9 & 10\end{array}$

11. In your opinion, what (Perpetrator name) did was...

Good,nice

Bad, awful

$\begin{array}{llllllllll}1 & 2 & 3 & 4 & 5 & 6 & 7 & 8 & 9 & 10\end{array}$

12. In your opinion, how generally blameworthy is the offender?

Not blameworthy

Very blameworthy

$\begin{array}{llllllllll}1 & 2 & 3 & 4 & 5 & 6 & 7 & 8 & 9 & 10\end{array}$

Please take a moment and THINK ABOUT THE CRIME in this instance of white-collar crime. Answer each of the following questions by choosing the number that corresponds to your judgment about the CRIME. Remember, there are no right or wrong answers.

13. Are you outraged by the crime against the victims?

Not at all

$\begin{array}{llllllllll}1 & 2 & 3 & 4 & 5 & 6 & 7 & 8 & 9 & 10\end{array}$


14. Has the victim suffered as a result of the crime?

Not at all

Extremely

$\begin{array}{llllllllll}1 & 2 & 3 & 4 & 5 & 6 & 7 & 8 & 9 & 10\end{array}$

15. Has the victim suffered physically as a result of the crime?

Not at all

Extremely

$\begin{array}{llllllllll}1 & 2 & 3 & 4 & 5 & 6 & 7 & 8 & 9 & 10\end{array}$

16. Has the victim suffered emotionally as a result of the crime?

Not at all

Extremely

$\begin{array}{llllllllll}1 & 2 & 3 & 4 & 5 & 6 & 7 & 8 & 9 & 10\end{array}$

17. Has the victim suffered financially as a result of the crime?

Not at all

Extremely

$\begin{array}{llllllllll}1 & 2 & 3 & 4 & 5 & 6 & 7 & 8 & 9 & 10\end{array}$

18. Was the crime insulting against the victims?

Not at all

Extremely

$\begin{array}{llllllllll}1 & 2 & 3 & 4 & 5 & 6 & 7 & 8 & 9 & 10\end{array}$

19. Was the crime disrespectful to the victims?

Not at all

Extremely

$\begin{array}{llllllllll}1 & 2 & 3 & 4 & 5 & 6 & 7 & 8 & 9 & 10\end{array}$

20. Was the crime offensive to the victims?

Not at all

Extremely 


$\begin{array}{llllllllll}1 & 2 & 3 & 4 & 5 & 6 & 7 & 8 & 9 & 10\end{array}$

21. How serious do you think white collar crime is?

Not at all

$\begin{array}{lllllllllll}\text { at all } & & & & & & & & & \text { Extremely } \\ 1 & 2 & 3 & 4 & 5 & 6 & 7 & 8 & 9 & 10\end{array}$

22. How serious of a crime do you think (name of their crime) is?

Not at all

$\begin{array}{llllllllll}1 & 2 & 3 & 4 & 5 & 6 & 7 & 8 & 9 & 10\end{array}$

Extremely

10

Now, imagine you are the judge deciding the SENTENCE the offender should receive. What sentencing would you recommend upon finding (perpetrators name) guilty of (the crimes mentioned in the case)?

23. What sentence would you recommend?

$1=$ Misdemeanor fine, no prison term

2=Probation with no prison term

$3=5$ Years with opportunity for parole

$4=10$ Years with opportunity for parole

$5=15$ Years with opportunity for parole

$6=20$ Years with opportunity for parole

$7=25$ Years with opportunity for parole

$8=$ Life Imprisonment with opportunity for parole

9= Life Imprisonment without parole

$10=$ Death Penalty

24. What is the minimum sentence you would agree upon?

$1=$ Misdemeanor fine, no prison term

2=Probation with no prison term 
$3=5$ Years with opportunity for parole

$4=10$ Years with opportunity for parole

$5=15$ Years with opportunity for parole

$6=20$ Years with opportunity for parole

$7=25$ Years with opportunity for parole

8= Life Imprisonment with opportunity for parole

9= Life Imprisonment without parole

$10=$ Death Penalty

25. What is the maximum sentence you would agree upon?

$1=$ Misdemeanor fine, no prison term

2=Probation with no prison term

$3=5$ Years with opportunity for parole

$4=10$ Years with opportunity for parole

$5=15$ Years with opportunity for parole

$6=20$ Years with opportunity for parole

$7=25$ Years with opportunity for parole

$8=$ Life Imprisonment with opportunity for parole

9= Life Imprisonment without parole

$10=$ Death Penalty

26. Do you know anyone who has been arrested for white-collar crime?

1. Yes

2. No

27. If you answered YES to the above question, who was this person?

1. Yourself

2. Acquaintance

3. Friend

4. Relative

5. Other

28. Do you know anyone who has been a victim of white-collar crime? 
1. Yes

2. No

29. If you answered YES to the above question, who was this person?

1. Yourself

2. Acquaintance

3. Friend

4. Relative

5. Other

Now we would like to collect a little more information about YOU. Remember that your answers will be kept confidential and anonymous.

30. What is your age?

1. 19 or younger

2. $20-21$

3. $22-23$

4. $24-25$

5. $26-27$

6. 28-29

7. 30 or Older

31. What best describes your race/ethnicity? (please choose only one)

1. Hispanic or Latino

2. American Indian or Alaska Native

3. Asian

4. Black or African American

5. Native Hawaiian or Pacific Islander

6. White

7. Other

8. More than one race

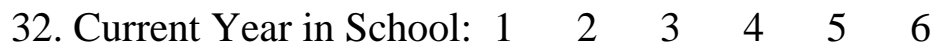

33. What is your academic major?

1. Undecided

2. Social/Behavioral Sciences (Sociology, Psychology, Anthropology, Political Science, Social Work, etc.)

3. Humanities (Art, English, Philosophy, History, Music, Journalism, Communications, Foreign Languages, etc.)

4. Engineering, Computer Science

5. Education

6. Natural/Physical Sciences (Agriculture, Biology, Chemistry, Geology, Physics, Mathematics, Pre-Med., Medicine, Natural Resources, Nursing, Pharmacy, etc.)

7. Business (Accounting, Management, Finance, Economics, etc.)

8. Other

34. Sex:

1. Male

2. Female

35. What was your high school grade point average at the time of graduation?

1. $0-.99$ 
2. $1.00-1.99$

3. 2.00-2.49

4. $2.50-2.99$

5. $3.00-3.49$

6. 3.50 or greater

36. If you have one, what is your current college grade point average?

1. 0-.99

2. 1.00-1.99

3. $2.00-2.49$

4. 2.50-2.99

5. $3.00-3.49$

6. 3.50 or greater

37. What is your parents' estimated yearly income?

1. $\$ 0-9,999$

2. $\$ 10,000-19,999$

3. $\$ 20,000-29,999$

4. $\$ 30,000-39,999$

5. $\$ 40,000-49,999$

6. $\$ 50,000-59,999$

7. $\$ 60,000-69,999$

8. $\$ 70,000-79,999$

9. $\$ 80,000-89,999$

10. $\$ 90,000$ - or greater 


\section{Appendix C}

\section{Experiment 1:}

\begin{tabular}{|c|c|}
$\begin{array}{c}\text { Offender Status } \\
\text { High }\end{array}$ & \\
\cline { 2 - 2 } Low & Condition 1 \\
\cline { 2 - 2 } & Condition 2 \\
\hline
\end{tabular}

\section{Overbilling}

Condition 1: High Status - Robert Sullivan is a lawyer. Robert overbills his clients for hours during which he did not work on their case, earning his firm an extra $\$ 10,000$ a year.

Condition 2: Low Status - Andrew Smith is a billing clerk for a construction company and is in charge of billing. Andrew overcharges clients for hours that construction crews did not work. Andrew's company profits $\$ 10,000$ a year from overbilling clients.

\section{Medical Fraud}

Condition 1: High Status - Dr. Lenard Holmes is a medical doctor Using his position as a medical doctor Dr. Holmes files false claims to an insurance company. Dr. Holmes adds services to patient's insurance claims, which the patients did not receive. As a result Dr. Holmes's practice earns an additional $\$ 50,000$ dollars a year from the fraudulent claims, which consequently raises his patient's insurance rates.

Condition 2: Low Status - Joshua Schmidt Joshua Schmidt, as a registered nurse files false claims to an insurance company. Joshua adds services to patient's insurance claims, which the patients did not receive. As a result, the practice Joshua works for earns an additional \$50,000 dollars a year from the fraudulent claims, which consequently raises patient's insurance rates.

\section{Experiment Two:}

\begin{tabular}{lcr|l|} 
& \multicolumn{2}{c}{ Seriousness } \\
\cline { 3 - 4 } Offender Status & High & Condition 1 & Condition 2 \\
\cline { 3 - 4 } & Low & Condition 3 & Condition 4 \\
\cline { 3 - 4 } & &
\end{tabular}

\section{Medical Fraud}


Condition 1: High Status High Seriousness - Dr. John Smith is a highly educated individual with an advanced degree, and is a surgeon. Dr. Smith knowingly files false claims on the behalf of patients charging them for services that they did not receive in order to receive higher reimbursements from their insurance companies. Dr. Smith profits $\$ 100,000$ from filing the false claims, as a consequence his patient's premiums are costlier and it becomes harder for some of his patients later claims for legitimate services to be approved.

Condition 2: High Status Low Seriousness - Dr. John Smith is a highly educated individual with an advanced degree, and is a surgeon. Dr. Smith knowingly files false claims on the behalf of patients charging them for services that they did not receive in order to receive higher reimbursements from their insurance companies. Dr. Smith profits $\$ 10,000$ from filing the false claims. His patient's insurance rates go up slightly, but they notice no difference in services.

Condition 3: Low Status High Seriousness - Adam O'Brien is a registered nurse. Adam takes medical supplies and drug samples from his office, which he charges to patient's insurance claims. Adam is able to sell the drugs and medical supplies at a profit of $\$ 100,000$. As a consequence patients of the office Adam works at are faced with higher premiums and it becomes harder for some of his patients later claims for legitimate services to be approved.

Condition 4: Low Status Low Seriousness - Adam O'Brien is a registered nurse. Adam takes medical supplies and drug samples from his office, which he charges to patient's insurance claims. Adam is able to sell the drugs and medical supplies at a profit of $\$ 10,000$. As a consequence patients of the office Adam works at are faced with slightly higher premiums, but they notice no real difference in services.

\section{Embezzlement}

Condition 1: High Status High Seriousness - Matthew Parks, as the CEO of a bank uses his position to steal money from bank customers over a two-year period. Matthew is able to embezzle over $\$ 2$ million from his clients.

Condition 2: High Status Low Seriousness - Matthew Parks, as the CEO of a bank uses his position to steal money from bank customers over a two-year period. Matthew is able to embezzle $\$ 10,000$ from his clients.

Condition 3: Low Status High Seriousness - Hank Manny, as a bank teller gets to personally know many of his customers and steals money from some of them over a two year period. Hank is able to embezzle over $\$ 2$ million dollars from bank customers.

Condition 4: Low Status Low Seriousness - Hank Manny, as a bank teller gets to personally know many of his customers and steals money from some of them over a two year period. Hank is able to embezzle $\$ 10,000$ from bank customers.

\section{Ponzi Scheme}


Condition 1: High Status High Seriousness - Daniel Jacobs is the CFO of a large financial investment company. Daniel uses his position as CFO to run a Ponzi scheme, cheating investors out of $\$ 100$ million. As a result of his Ponzi scheme, Daniels company goes bankrupt loosing 5,000 jobs, and some of his investors lose their entire life savings.

Condition 2: High Status Low Seriousness - Daniel Jacobs is the CFO of a large financial investment company. Daniel uses his position as CFO to run a small Ponzi scheme, cheating investors out of $\$ 10,000$. As a result of his Ponzi scheme Daniel's company faces small fines, and some of his investors loose a small portion of their savings.

Condition 3: Low Status High Seriousness - Caleb is a middle manager at a vitamin water sales company. Caleb runs a pyramid scheme at the company, profiting $\$ 50,000$. As a result of the pyramid scheme many employees loose a significant portion of their savings and they all lose their jobs.

Condition 4: Low Status Low Seriousness - Caleb is a middle manager at a vitamin water sales company. Caleb runs a pyramid scheme at the company, profiting $\$ 10,000$. As a result of the pyramid scheme some employees loose a small portion of their savings.

\section{Overbilling}

Condition 1: Robert Sullivan is a lawyer who works for a large law firm in a major city. Robert overbills his clients for hours during which he did not work on their case. As a result, Robert's firm earns an extra $\$ 100,000$ a year.

Condition 2: Robert Sullivan is a lawyer who works for a large law firm in a major city. Robert overbills his clients for hours during which he did not work on their case. As a result, Robert's firm earns an extra $\$ 10,000$ a year.

Condition 3: Andrew Smith is a billing clerk for a construction company. Andrew overcharges clients for hours that construction crews did not work. Andrew's company profits $\$ 100,000$ a year from overbilling clients.

Condition 4: Andrew Smith is a billing clerk for a construction company. Andrew overcharges clients for hours that construction crews did not work. Andrew's company profits $\$ 10,000$ a year from overbilling clients. 